\title{
Description of three species of ophioplinthacids, including a new species, from a deep seamount in the Northwest Pacific Ocean
}

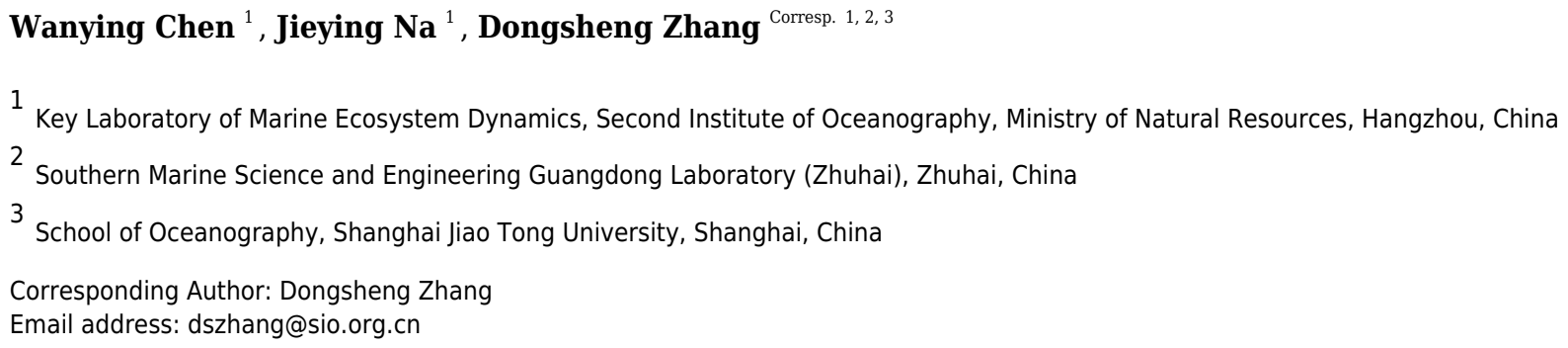

Five specimens of brittle star were collected from a deep-sea seamount in the Northwest Pacific, and identified into three species. One of which is new to science, Ophioplinthaca grandisquama $\mathrm{n}$. sp., can be easily distinguished from its congeners by the distinctly elongated and stout tentacle scales, stout and long disc spines, capitate with typically elongate to flaring head bearing numerous distinct thorns, radial shields roughly triangular and contiguous distally. One specimen was identified as Ophioplinthaca semele (A.H. Clark, 1949), which had been reported in Hawaii seamounts, is a new record of this species in the Northwest Pacific. The remaining specimen was an unknown species of Ophioplinthaca, with some different characteristics from other species of Ophioplinthaca. However, we, herein, prefer not to attach a name to this specimen until more morphological characteristics are available. The finding of this new species and two new records further enriches the distribution of Ophioplinthaca in the seamount of Northwest Pacific, providing useful information for marine protection in the cobalt-rich area. 
1 Description of three species of ophioplinthacids,

2 including a new species, from a deep seamount in the

3 Northwest Pacific Ocean

4 Wanying Chen ${ }^{1}$, Jieying $\mathrm{Na}^{1}$, Dongsheng Zhang ${ }^{1,2,3}$

$5 \quad{ }^{1}$ Key Laboratory of Marine Ecosystem Dynamics, Second Institute of Oceanography, MNR,

6 Hangzhou 310012, China

7 '2Southern Marine Science and Engineering Guangdong Laboratory (Zhuhai), Zhuhai 519082,

8 China

$9{ }^{3}$ School of Oceanography, Shanghai Jiao Tong University, Shanghai 200240, China

10 Corresponding Author:

11 Dongsheng Zhang ${ }^{1,2,3}$

1236 Baochubei Road, Hangzhou, Zhejiang, 310012, PR China

13 Email address: dszhang@sio.org.cn

14 Abstract

Five specimens of brittle star were collected from a deep-sea seamount in the Northwest Pacific, and identified into three species. One of which is new to science, Ophioplinthaca grandisquama n. sp., can be easily distinguished from its congeners by the distinctly elongated and stout tentacle scales, stout and long disc spines, capitate with typically elongate to flaring head bearing numerous distinct thorns, radial shields roughly triangular and contiguous distally. One specimen was identified as Ophioplinthaca semele (A.H. Clark, 1949), which had been reported in Hawaii seamounts, is a new record of this species in the Northwest Pacific. The remaining specimen was an unknown species of Ophioplinthaca, with some different characteristics from other species of Ophioplinthaca. However, we, herein, prefer not to attach a name to this specimen until more morphological characteristics are available. The finding of this new species and two new records further enriches the distribution of Ophioplinthaca in the seamount of Northwest Pacific, providing useful information for marine protection in the cobalt-rich area.

\section{Introduction}

Ophioplinthaca Verrill, 1899 is a genus in the family Ophiacanthidae Ljungman, 1867

which is distinguished from other Ophiacanthid genera by the deep interradial incisions into the disc which are lined distally by enlarged disc plates (O'Hara \& Stöhr, 2006). Ophioplinthaca is a widely distributed genus, and according to WoRMS (Stöhr et al., 2021), thirty-one valid species are known around the world. Among which, twenty-one species have been found occurring in the Indo-Pacific Ocean, six in the West Indian Ocean, and seven in the Atlantic Ocean (Cherbonnier \& Sibuet, 1972; O’Hara \& Stöhr, 2006; Clark, 1949; Clark, 1939; Clark, 1911; 
Lyman, 1878; Thomson, 1877; Koehler, 1904; Koehler, 1930; Koehler, 1922; John \& Clark, 1954; Lyman, 1883; Guille, 1981; Koehler, 1897; Mortensen, 1933; Clark, 1900). Recently, it was suggested that Ophioplinthaca is one of the dominant groups of megafauna on seamounts (O'Hara, Rowden \& Williams, 2008; Cho \& Shank, 2010). The northwest Pacific region has the highest number of seamounts globally (Yesson et al., 2011), and many of the seamounts are covered with cobalt-rich ferromanganese crusts, which is a valuable mineral (Hein et al., 2009). However, few studies of Ophiuroid in this area has been reported (Litvinova, 1981; Zhang et al., 2018; Na et al., 2019).

In 2019, several Ophioplinthaca specimens were collected from RC seamount in the Northwest Pacific by a Remotely Operated Vehicle (ROV). Three specimens were determined to be a new species of genus Ophioplinthaca which we described herein. The other two specimens, identifed as Ophioplinthaca semele and an unknown species, were described here as new records of ophioplinthacids in the Northwest Pacific Ocean. This study provides biodiversity information of seamounts in the cobalt-rich area, which may be useful for marine protection from future deep-sea mining.

\section{Materials \& Methods}

Ophiuroid specimens from a seamount in the Northwest Pacific Ocean were collected during cruise DY56 using an ROV HAILONG III. Sampling sites are shown in Fig. 1. Specimens were fixed in $90 \%$ ethanol on board and deposited in the sample Repository of the Second Institute of Oceanography (RSIO), Ministry of Natural Resources, Hangzhou, China.

Specimens were examined and photographed using a stereoscopic microscope (Zeiss Axio Zoom.V16). Arm skeletal elements were obtained after submerging in commercial bleach (2.5\% $\mathrm{NaOCl}$ ), until all soft issue dissolved, washed in distilled water, air-dried and then mounted on stubs, imaged using a Hitachi TM1000 scanning electron microscope.

Genomic DNA was extracted from arm tissue using DNeasy® Blood \& Tissue Kit (QIAGEN) following the manufacturers' protocols. The mitochondrial COI sequences were amplified with primers listed in Table 1. PCR reactions were performed using $50 \mu \mathrm{L}$ volumes containing: $5 \mu \mathrm{L} 10 \times$ Buffer (containing $\mathrm{Mg}^{2+}$ ), $10 \mathrm{mM}$ of each $\mathrm{dNTP}, 0.1 \mathrm{mM}$ of each primer, $37.5 \mu \mathrm{L}$ of $\mathrm{ddH}_{2} \mathrm{O}, 2.5 \mathrm{U}$ of Taq DNA Polymerase (Vazyme, China), and $2 \mu \mathrm{L}$ of DNA template. PCR products were purified with QIAquick PCR purification kit (QIAGEN) following the 
67 protocol supplied by the manufacturer. Sequencing was performed by Sangon Biotech

68 (Shanghai, China) on an ABI 3730XL DNA analyzer (Applied Biosystems).

69

70

71

72

73

74

75

76

77

78

79

80

81

82

83

84

85

86

87

88

89

90

91

92

93

94

95 Results

96 Systematics

97 Class Ophiuroidea Gray, 1840 steps and a relative gap width of 1.0.

\section{Nomenclatural acts} BOLD database (Table 2). In this study, we included another two COI sequences of $O$. defensor from a recent study (Na et al., 2021). In total, 19 COI sequences (Table 2), including 5 new sequences and 2 sequences from Ophiacantha as outgroup, were used for phylogenetic analysis. COI sequences were aligned using Geneious Prime 2019 with default settings. Phylogenetic analysis was conducted by RAxML (Stamatakis, 2014), with a 1000-replicate bootstrap support value for each node and a GTR $+\mathrm{I}+\mathrm{G}$ substitution model. The model was selected by the software of jmodeltest-2.1.10, and the AIC selection results showed the best model was GTR $+\mathrm{I}+\mathrm{G}$.

Pairwised genetic distance (K2P) were calculated for COI sequences in MEGA6 (Tamura et al., 2013). The Automatic Barcode Gap Discovery (ABGD) analysis (Puillandre et al., 2012) was carried out on the web interface (https://bioinfo.mnhn.fr/abi/public/abgd/abgdweb.html) to establish molecular operational taxonomic units (MOTUs) from COI gene sequence data. The Kimura (K80) model (Kimura, 1980) with a TS/TV of 2.0 (K2P), Pmin $=0.001$, Pmax $=0.1,10$

The electronic version of this article in Portable Document Format (PDF) will represent a published work according to the International Commission on Zoological Nomenclature (ICZN), and hence the new names contained in the electronic version are effectively published under that Code from the electronic edition alone. This published work and the nomenclatural acts it contains have been registered in ZooBank, the online registration system for the ICZN. The ZooBank LSIDs (Life Science Identifiers) can be resolved and the associated information viewed through any standard web browser by appending the LSID to the prefix http://zoobank.org/. The LSID for this publication is: urn:lsid:zoobank.org:pub:A48B7301-0D4B-4280-BF81639689F923F6. The online version of this work is archived and available from the following digital repositories: PeerJ, PubMed Central and CLOCKSS. 
98 Order Ophiacanthida O’Hara, Hugall, Thuy, Stöhr and Martynov, 2017

99 Family Ophiacanthidae Ljungman, 1867

100 Genus Ophioplinthaca Verrill, 1899

101 Ophioplinthaca grandisquama n. sp. (Fig. 2-5)

102 urn:lsid:zoobank.org:act:8509E6DB-E902-4A71-9339-EA40725DD688

103 Material examined. - St. RC-ROV05, $161.78^{\circ} \mathrm{E}, 15.54^{\circ} \mathrm{N}, 1049 \mathrm{~m}$, September 17, 2019, 3

104 specimens (RSIO56013, RSIO56014, RSIO56060).

105 Habitat. All three specimens of the new species were attached to a Calyptrophora (Fig. 2).

106 Etymology. The specific name alludes to the large and long tentacle scales.

107 Description of the holotype. Disc $7 \mathrm{~mm}$ d.d., high $3.7 \mathrm{~mm}$, five arms, seven times of the disk

108 diameter in length. Disc incised interradially more than $1 / 5$ d.d. creating five wedge-shaped

109 divisions in contrast to the sunken centre and interradii of the disc (Fig. 3A). Each division on

110 aboral surface covered by a pair of large radial shields and a number of irregular plates. Radial

111 shields naked, triangular, about $1 / 4$ d.d. in length, one and a half times as long as wide with a

112 truncate distal edge and a sharp proximal angle, broadly contiguous distally (Fig. 3A). Disc

113 plates overlapping, covered with distinctly elongated disc spines, not enlarged distal to the radial

114 shields interradially. Disc spines stout, up to $0.8 \mathrm{~mm}$ in length, 4-6 times as high as wide, bearing

115 numerous distinct thorns on lateral side or apex, some capitate and bifurcated into two prongs at

116 the top, one of the two prongs elongated and inflated. (Fig. 3B, 5A). Ventral disc surface covered

117 in small and overlapped plates, few of which bear spines thinner than those on the dorsal surface.

118 Genital slits wide, extending from the oral shields to the dorsal disc surface (Fig. 3C).

119 Oral shields arrow-head-like shape, with an obtuse proximal angle, rounded laterals and a

120 small obtuse distal lobe, 2 times as wide as long, one of which is expanded as madreporite.

121 Adoral plates quadrilateral, 2 times as long as wide, not separating the oral shields from the

122 lateral arm plate. Jaw triangular, wider than long with 1-2 blunt and serrated dental papillae, and

123 3-4 conical lateral oral papillae longer than wide with pointed tip, the distal one slightly widened

124 (Fig. 3C). Infradental papilla, adoral plate papillae and lateral oral papillae quite similar in shape

125 so in this study and for descriptive purposes, the ossicles on oral edge of oral plate are all called

126 lateral oral papillae. One oral tentacle scale situated at the end of the jaw slit, slightly larger than

127 oral papillae, often longer than wide with a rounded free edge and covered by distal oral papillae.

Peer] reviewing PDF | (2020:11:55728:3:0:NEW 11 May 2021) 
128

129

130

131

132

133

134

135

136

137

138

139

140

141

142

143

144

145

146

147

148

149

150

151

152

153

154

155

156

157

158

Five arms, wide and slightly moniliform. Dorsal arm plates trapezoid to triangular with slightly convex distal edge on proximal segments, contiguous to each other; on distal segments dorsal arm plates change to fan-shaped and just contiguous (Fig. 3D). First ventral arm plates trapezoid much wider than long with a short proximal edge, concave and diverging lateral edges, distal margin much wider. The following plates become pentagonal, slightly wider than long, with a sharp proximal angle, diverging lateral sides which are widely excavated by the corresponding tentacle scales, distal margin board and convex, all separated from each other (Fig. 3E). Tentacle pores covered on the first segments with one or two leaf-shaped scales; one fusiform or conical tentacle scale from the second segments, elongated and thorny with a thick base tapering into a blunt point, slightly longer than one arm segment (Fig. 3C, E). Arm spines seven, up to three arm segments in length on proximal arm segments, dorsally four arm spines are thin with distinct lateral thorns, tapering into a sharp point, the second dorsal-most arm spines longest; ventral arm spines shorter and blunt, finely rugose (Fig. 3D). Color in life orangebrown.

Description of paratypes. The two paratypes (RSIO56013, RSIO56014) share the same morphological characteristics with the holotype (Fig. 4A-D, 5A-E). For one of the two paratypes (RSIO56014) (Fig. 4A, B), the oral structure is incomplete with one of five oral plate sets is missing, which may be due to the malformation or predation. The remaining oral shields are relatively smaller than the holotype, adoral plates are wider. The other paratype (RSIO56013) with stronger disc spines, elongate to flaring head bearing numerous distinct thorns, up to 1.4 $\mathrm{mm}$ in length, 4-6 times as high as wide (Fig. 4C, D). Tentacle pores covered, on the proximal arm segments one elongated scale with a rounded base tapering to a blunt point.

Description of the skeletal elements (Paratype: RSIO56014): Oral plates longer than high, with a small pore for water ring canals, abradial muscle fossa large with finer mesh stereom than remaining ossicle (Fig. 5F). A row of three papilla sockets and pores near lower edge of adradial proximal oral plate as articulations of oral papillae; conspicuous s-curved suture line crosses foot basin (Fig. 5G). Dental plate entire with single column of wide sockets, with low dorsal and ventral border, not penetrating (Fig. 5H). Adradial genital plate long, articulation surface with slightly elevated elongated condyle (Fig. 5I, K); abradial genital plate slightly smaller in size than adradial plate and articulating proximal to the adradial plate condyle (Fig. 5J). Radial shield longer than wide, with abradial projection and convex radial edge (Fig. 5L). Internally, radial 
159 shield with one distal domed condyle and one depression, which articulated with genital plate 160 (Fig. 5M).

161 The vertebrae articulation zygospondylous, wider than long in proximal segments and gradually

162 changes to longer than wide from the middle to distal segments, with zygapophyses framing the 163 water vascular canal on proximal side (Fig. 5N-R).A longitudinal groove on oral side (Fig. 3Q), 164 with a pair of lateral ambulacral canals opening inside the oral groove (Fig. 3Q); the podial 165 basins on the oral side are small, $127 \mu \mathrm{m}$ in diameter (Fig. 5Q); an aboral groove on the aboral 166 side is slightly expressed without extension (Fig. 5R). Lateral arm plates (LAP) with constriction 167 in proximal part leading to raised distal portion (Fig. 5S). The external surface of the LAP 168 consisted of regularly meshed stereom, mesh size gradually decreasing from the middle to the 169 proximal margin, while in the distal part, mesh size is mostly small but larger near the distal 170 margin (Fig. 5S). Arm spine articulations well developed, volute-shaped, dorsal and ventral lobes 171 merged at their proximal tips, sigmoidal fold present (Fig. 5S). The muscle opening is larger than 172 the nerve opening (Fig. 5S). On the internal side are a row of perforations on the central of 173 middle part, parallel to the arrangement of spine articulation (Fig. 5T); a continuous ridge and a 174 prominent knob close to the ventral edge forming vertebral articular structures, of which shape is 175 reminiscent of an undivided digit 1 with a broad, nose-shaped beak (Fig. 5T).

176 Remark. Ophioplinthaca grandisquama n. sp. is characterized by the stout disc spines, capitate 177 with typically elongate to flaring head bearing numerous distinct thorns, radial shields roughly 178 triangular, about 1/4 d.d. in length and contiguous distally, the tentacle scales elongated and 179 stout. The thick tentacle scales in O. grandisquama n. sp. are elongated with a rounded base 180 tapering to a blunt point and covered in irregular thorns similar to arm spines, which is distinctly 181 distinguished from its congeners and most of them bearing oval or leaf-shaped tentacle scales 182 (Thomson C.W., 1877; Lyman, 1878; Lyman, 1883; Clark H.L., 1900; Koehler, 1904; Clark 183 H.L., 1911; Koehler, 1922; Mortensen, 1933; Clark H.L., 1939; Koehler, 1930; Clark A.H., 184 1949; John \& A.M. Clark, 1954; Cherbonnier \& Sibuet, 1972; Guille, 1981; O’Hara \& Stöhr, 185 2006) (Table 3).

186 The sizes and shapes of radial shields and disc spines have been suggested to be the primary 187 criteria for delimiting species (O’Hara \& Stöhr, 2006). We compared the key morphological 188 characters among species from the genus Ophioplinthaca (Table 3). O. hastata Koehler, 1922 189 and O. globata Koehler, 1922, which resemble the new species mostly, also have stout and 
190 capitate disc spines. However, in O. grandisquama n. sp., the disc spines are more elongated, 4-6 191 times as high as wide, bearing numerous distinct thorns all over the whole spine except the basal 192 trunk, whereas the disc spines are only 2-3 times as high as wide, capitate with a convex to 193 flaring head bearing numerous small thorns in $O$. hastata, and are cylindrical to conical with 194 obvious thorns only in the upper half in $O$. globata with similar height-width ratio to $O$. hastata 195 (O’Hara \& Stöhr, 2006). Radial shields are relatively small, in O. hastata and O. globata, with 196 $1 / 6$ d.d. and $1 / 5$ to $1 / 8$ d.d. in length, respectively, and contiguous distally or separate, instead of 197 $1 / 4$ d.d. in length, broadly contiguous distally in the new species. Additionally, dorsal arm plates 198 are also different between the new species and $O$. hastata and O. globata. Dorsal arm plates are a 199 little longer than wide or as wide as long, separated from the basal arm segments, instead of contiguous at least on proximal segments in $O$. grandisquama $\mathrm{n}$. sp.

201

Other species, O. amezianeae O'Hara \& Stöhr, 2006 and O. rudis (Koehler, 1897), were

202 described with elongated spines, greater than 3 times as high as wide in this genus. The former is clearly different from O.grandisquama $\mathrm{n}$. sp. in having slender disc spines, with a rounded base tapering to a sharp point or terminating in 2-3 small thorns, radial shields separate, oral shields as long as wide. The latter can be distinguished by having needle-like disc spines, long and slender, 206 up to $1.3 \mathrm{~mm}$ in length, smooth to finely serrate, pentagonal oral shields, and bottle-shaped to pointed tentacle scales, half as long as the ventral arm plate.

208

Ophioplinthaca semele (A.H. Clark, 1949) (Fig. 6-8)

Material examined. - St. RC-ROV08, $161.81^{\circ} \mathrm{E}, 15.53^{\circ} \mathrm{N}, 1024 \mathrm{~m}$, September 20, 2019, 1

211 specimen (RSIO56057).

212 Habitat and Distribution. This specimen was found attaching on a blade-like glass sponge

213 together with a sea lilly (Fig. 6). The holotype and other specimens were collected near Hawaii 214 (537-1250m); this is the first record of this species from a seamount in the Northwest Pacific $215(1024 \mathrm{~m})$.

216 Description of morphological characteristics. Disc $11.2 \mathrm{~mm}$ d.d., high $5.4 \mathrm{~mm}$, five arms, 217 seven times of the disk diameter in length. Disc almost incised interradially $1 / 3$ d.d., creating five 218 wedge-shaped divisions covered by a pair of large, naked radial shields and a number of irregular 219 plates (Fig. 7A). Radial shields triangular, about 1/3 d.d. in length, 1.5-2 times as long as wide 220 with a truncate distal edge and blunt proximal angles, contiguous for 1/3-1/2 of the length (Fig. 
221 7B). Disc plates overlapping, bearing cylindrical swollen stumps, up to $0.5 \mathrm{~mm}$ high, covered in 222 obvious thorns on the upper half (Fig. 7C, 8A). Disc spines at the distal margin and between 223 radial shields are thinner with less thorns (Fig. 7C). Ventral disc surface covered in small 224 overlapping plates, without spines. Genital slits long and wide (Fig. 7D).

Oral shields diamond-shaped, with an obtuse proximal angle, rounded laterals and an obtuse to lobed distal angle, 2 times as wide as long, one of which expanded as madreporite (Fig. 7D).

227 Adoral plates quadrilateral, large and broad, two times as long as wide, not separating the oral shields from the first lateral arm plate. Jaw triangular, as long as wide with 2-3 thin and long dental papillae. Lateral oral papillae 4-5, pointed, up to 3 times longer than wide, and the distal two oral papillae slightly broadened and leaf-shaped, standing erect, abutting the elongated oral tentacle scale (Fig. 7D).

Five arms, wide and slightly moniliform. First dorsal arm plate wider than long with obtuse proximal angle and straight distal border. Succeeding plates triangular to scallop-shaped with convex distal edge, slightly wider than long, separated from each other (Fig. 7B, E, 8B). Ventral arm plates pentagonal with a sharp proximal angle, diverging lateral sides which are very widely excavated by the corresponding tentacle scales, distal side convex, widely separated from each other (Fig. 7F, 8C). Tentacle pores on the first arm segments, covered with one or two scales, leaf-like, pointed and spiniform, more than half length of ventral arm plates, decreasing to one scale thereafter until nearly the end of the arm (Fig. 7D, F). The proximal arm segments bearing up to eight arm spines, with sharp tip and distinct teeth, almost meeting each other on the dorsal mid-line on the fourth segment (Fig. 7E). The third dorsalmost arm spines are the longest, up to three segments in length, lowermost shortest, one segment in length. As the arm segments reduced distally, arm spines reduced to five. Color in life orange-white.

Description of the skeletal elements. The vertebrae articulation zygospondylous, wider than long in proximal segments, gradually changing to longer than wide from the middle to distal segments, with zagapophyses framing the water vascular canal on proximal side (Fig. 8D-H). The aboral groove on the dorsal side is moderately expressed without extension (Fig. 8E); a longitudinal groove on oral side (Fig. 8F), with a pair of lateral ambulacral canals opening inside the oral groove (Fig. 8F); the podial basins on the oral side are small (Fig. 8F). LAP with constriction in proximal part leading to raised distal portion. Arm spine articulations well developed, volute-shaped, dorsal and ventral lobes merged at their proximal tips, sigmoidal fold 
252 present (Fig. 8I). The muscle opening is larger than the nerve opening. On the internal side, a 253 group of small, irregular perforations parallel to the arrangement of spine articulation; a 254 continuous ridge and a prominent knob forming vertebral articular structures, of which shape is 255 reminiscent of an undivided digit one with a broad, nose-shaped beak (Fig. 8J).

256 Remark. This specimen was identified as O. semele (A.H. Clark, 1949) based on the multiple 257 apical papillae, large radial shields contiguous for 1/3-1/2 of the length distally, cylindrical disc

258

259

260

261

262

263

264

265 266

267

268

269

270

271

272

273

274

275

276

277

278

279

280

281

282 stumps with obvious thorns on the top and upper half. It also has some slight differences, having two or three shaped and leaf-shaped tentacle scales on the first tentacle pore instead of three or more broad and spoon-shaped scales in the holotype, adoral plates complete instead of divided into two or more plates in the holotype. Clark (1949) described the differences in tentacle scales and lateral oral papillae between the two smaller specimens and the holotype. Furthermore, tentacle scale morphology is not reliable for species delimitating in the genus Ophioplinthaca (O’Hara \& Stöhr, 2006). Therefore, with only one specimen of this species in our collection, these differences are attributed to inter-species variation rather than characteristics for taxonomic delimitation.

The cylindrical disc granules with a flaring top of a few thorns are reminiscent of Ophioplinthaca citata Koehler, 1904 from the New Caledonia, which differed in having narrower radial shields, contiguous dorsal and ventral arm plates and single ventral-most teeth (O’Hara \& Stöhr, 2006). Several other species are also close to O. semele in the shape of disc spines. Ophioplinthaca globata also has cylindrical to conical granules, the upper half covered in obvious thorns, but can be differentiated in having a single ventral-most tooth, and some other differences such as size and shape of radial shields and jaws, and number of arm spines (Koehler, 1922; O’Hara \& Stöhr, 2006). Ophioplinthaca clothilde A.H. Clark, 1949 has stumps terminating in flaring irregular crown of a dozen or more spines, and O. lithosora (H.L. Clark, 1911) has low cylindrical stumps with two to six tiny thorns near the apex. But they can be distinctly distinguished by size of radial shields and the number of apical papillae.

Ophioplinthaca sp. (Fig. 9-11)

Material examined. - St. RC-ROV08, $161.80^{\circ} \mathrm{E}, 15.52^{\circ} \mathrm{N}, 1146 \mathrm{~m}$, September 20, 2019, 1 specimen (RSIO56058).

Habitat. This specimen was found attaching on a Narella (Fig. 9). 
283 Description of morphological characteristics. Disc $10.4 \mathrm{~mm}$ d.d., high $4.2 \mathrm{~mm}$, arms seven 284 times d.d.. Disc incised interradially 1/3 d.d., creating a wedge over each arm base, wedges 285 tumid, in contrast to the sunken centre and interradii of disc (Fig. 10A). Radial shields naked, 286 triangular, more than 1/4 d.d. in length, 1.5 2 times as long as wide with a round distal margin 287 and a sharp proximal angle, distally contiguous more than half of the length, and separated 288 289 proximally by a triangular plate (Fig. 10A). The center of the disc is occupied by small irregular plates, bearing small granules up to $0.25 \mathrm{~mm}$ high, $1 \sim 1.5$ times as high as wide, cylindrical to capitate with a terminal crown of thorns (Fig. 10B, 11A). Ventral disc surface covered in small and uneven plates without granules (Fig. 10C). Genital slits long and wide.

Oral shields diamond-shaped, with an obtuse proximal angle, rounded laterals and an obtuse to lobed distal angle, 2 times as wide as long, one of which is expanded into a madreporite (Fig. 10C). Adoral plates quadrilateral, 3 times as long as wide, not separating the oral shields from the first lateral arm plate. Jaw triangular, wider than long with 1 blunt dental papilla, and 3 lateral oral papillae that are swollen and conical, gradually decreasing in size from inside to outside. One large oral tentacle scale situated under the distal oral papillae, conical and elongate, up to 2 mm long (Fig. 10C).

Five arms, wide and slightly moniliform. Dorsal arm plates triangular to scallop-shaped 300 with convex distal edge, separated from each other (Fig. 10D, 11B). Ventral arm plates pentagonal, separated from each other, with a small proximal angle, diverging lateral sides which are excavated by the corresponding tentacle pores, and distal side convex (Fig. 10C, E, 11C). Tentacle pores on the first arm segments, covered with one or two scales, decreasing to one scale thereafter to the end of the arm. Tentacle scales thick and smooth on the basal segments, change to smaller, leaf-like and thorny on the following segments, almost half length of the ventral arm plates (Fig. 10C, E). The proximal arm segments with up to seven spines, of which the dorsally second or third are the longest, three segments in length, lowermost shortest, one segment in length (Fig. 10D). The number of arm spines reduced to four on distal segments.

Description of the skeletal elements. The vertebrae articulation zygospondylous, wider than long in proximal segments and gradually changing to longer than wide on middle to distal segments, with zagapophyses framing the water vascular canal on proximal side (Fig. 11D-H).

312 The aboral groove on the dorsal side is moderately expressed without extension (Fig. 11E); a longitudinal groove on oral side (Fig. 11F), with a pair of lateral ambulacral canals opening 
314 inside the oral groove (Fig. 11F); the podial basins on the oral side are small (Fig. 11F, H). LAPs

315 with constriction in proximal part leading to raised distal portion (Fig. 11I). Arm spine

316 articulations well developed, volute-shaped, dorsal and ventral lobes merged at their proximal

317 tips, sigmoidal fold present (Fig. 11I). The muscle opening is larger than the nerve opening (Fig.

318 11I). On the internal side, a group of small, irregular perforations parallel to the arrangement of

319 spine articulation; a continuous ridge and a prominent knob forming vertebral articular

320 structures, of which shape is reminiscent of an undivided digit one with a broad, nose-shaped

321 beak (Fig. 11J).

322 Remark. This specimen is characterized by the deep interradial incisions, radial shields twice as

323 long as wide, 1/4 d.d. in length, contiguous for most of their length, the disc spines cylindrical to

324 capitate with a terminal crown of thorns, and jaw wider than long with 1 blunt dental papilla and

3253 small lateral oral papillae in each side, gradually decreasing in size from inside to outside.

326 Ophioplinthaca pulchra Koehler, 1904 is similar to our specimen in the shape of disc spines, but

327 it differs in having some spherical and smooth disc granules, large radial shields, up to $1 / 3 \mathrm{~mm}$

328 d.d., only contiguous distally, oral shields much longer than wide, and four pointed to square-

329 shaped lateral oral papillae in each side. Ophioplinthaca pulchra is quite similar to

330 Ophioplinthaca plicata (Lyman, 1878), and can be difficult to distinguish. Ophioplinthaca

331 plicata is highly variable, particularly in the shape of the disc stumps, the position of the radial

332 shields, and the shape of oral shields (O'Hara \& Stöhr, 2006). Some features of this specimen

333 fall within the range of variation, such as the broadly contiguous radial shield and small oral

334 shield, but the capitate disc spines and only three small lateral oral papillae on each side of jaws

335 can be distinguished from O.plicata. However, the limits of species in genus Ophioplinthaca are

336 obscure (O'Hara \& Stöhr, 2006) and with only one specimen, it is impossible to provide a full

337 description of the range of variation and stable characteristics for diagnosis, therefore, we prefer 338 not to attach a name to this single specimen.

339 Lateral arm plate characteristics

340 Lateral arm plates (LAPs) have been suggested to the key taxonomic character for

341 Ophiuroidea (Martynov, 2010), and are potentially identifiable to species level (Thuy \& Stöhr,

342 2011; Thuy \& Stöhr, 2016). Spine articulations of LAPs have been amply studied in recent

343 systematic studies (Thuy \& Stöhr, 2011, 2016; Stöhr et al., 2012; Thuy, 2013; O' Hara et al.,

344 2018). However, recent research suggested that some of species displayed indistinguishable 
345 lateral arm plate morphologies, but belonged to the same genus in all cases (Thuy \& Stöhr,

346 2011). Our study endorses the use of vertebral articular structures for taxonomic interpretations,

347 including species and genus identifications, providing that descriptions are based on pristinely

348 preserved proximal LAPs.

349 There have been few studies on the ridges and knobs (vertebral articular structures) on the 350 inner side of the lateral arm plates, in contrast, although they were recently confirmed to be 351 diagnostic on various taxonomic levels (Thuy \& Stöhr, 2011, 2016; Stöhr et al., 2012; Thuy, 352 2013; Numberger-Thuy et al., 2020). Numberger-Thuy et al. (2020) introduced 'vertebral articular 353 structures of the lateral arm plate' as an anatomically consistent term to designate all ridges, 354 knobs and other structures on the inner side of the lateral arm plate, and examined the shape of 355 vertebral articular structures of several Ophiacanthid species. Among which, the vertebral 356 articular structures of species Ophioplinthaca plicata was similar to Ophiacantha serrata which

357

358 359 360

361

362

363

364

365

366

367

368

369

370

371

372

373

374 375 has close relationship with the genus Ophioplinthaca, like an undivided digit 1 with a broad, nose-shaped beak. To test whether LAP is useful in distinguishing species in the genus Ophioplinthaca, LAPs of the three species described in this study and $O$. defensor reported by $\mathrm{Na}$ et al (2021) were compared (Fig. 12). The shape of vertebral articular structures of the four Ophioplinthaca species are consistent with O. plicata (Numberger-Thuy et al., 2020), an undivided digit one with a broad, nose-shaped beak, supporting the monophyly of the genus Ophioplinthaca. The shape of vertebral articular structures changed from the proximal to distal segments, and the "beak" on the proximal edges gradually shrank but not divided in the mid- or distal segments. Although vertebral articular structures were similar among Ophioplinthaca species, there were is slight differences between the four species, in the shape of the undivided digit " 1 " and the nose-like "beak". In the new species, the "beak" was more like hook nose, with two sharp acute angles proximally (Fig. 12 A). For the other three species herein, the "beaks" were distinctly broadened compared to the new species. For the $O$. semele, the "beak" curved proximal-ward with an extremely blunt angle dorsally. For $O$. defensor and $O$. sp., the "beaks" were close to that in O. plicata (Numberger-Thuy et al., 2020), in right triangle shape, but slightly curved proximal-ward (Fig. 12G, J). Furthermore, the right root serif was slender in O. semele and $O$. defensor, similar to O. plicata, but stouter in $O$. grandisquama n. sp. and $O$. sp. In general, the vertebral articular structure seems to be a potentially useful characteristic for identification at species level, especially for the genus Ophioplinthaca, which is morphologically 
376 confusing among species. However, with only limited material examined, it's still difficult make

377 any conclusion. An exhaustive investigation on lateral arm plates is required to assess these

378 characteristics for taxonomic identification.

\section{Phylogeny}

380

381

The phylogenetic analysis (Fig. 13) supported that O. grandisquama n. sp. is clearly distinguished from other species of Ophioplinthaca, supporting that the three specimens belong

382

383

384

385

386

387

388

389

390

391

392

393

394

395

396

397

398

399

400

401

402

403

404

405

to the same species. The maximum likelihood tree showed that $O$. semele was clustered with $O$.

rudis, whereas Ophioplinthaca $s p$. was clustered with $O$. globata, together forming a sister clade to O. plicata. Although the genetic distances among the four species were low (ranging from 0.032-0.078) (Table 4), the ABGD results supported that they are different species. Additionally, $O$. semele was closely related to $O$. rudis, they can be easily differed from each other based on the morphological characteristics, especially in the shape of disc spines, which are needle-like, long and slender in O.rudis instead of cylindrical with obvious thorns on the upper half in O.semele. Ophioplinthaca globata differs from $O$. sp. in having variable disc spines, many cylindrical to conical, others with only 3 terminal thorns or trifid with bifurcated tips, and radial shields $1 / 5-1 / 8$ d.d. in length, only contiguous distally or completely separated, whereas in O.sp, radial shields $1 / 4$ d.d. in length, contiguous for most of their length, and the disc spines cylindrical to capitate with a terminal crown of thorns.

The average intraspecific distances (Table 4) were 0.000-0.012 (O. plicata), 0.002-0.009 (O. grandisquama n. sp.), 0.001-0.028 (O. defensor) and 0.049 (O. pulchra). Two previsou studies suggested that the intraspecific distance ranged from 0.005 to 0.064 (Boissin et al., 2017) and from 0.000 to 0.057 (Christodoulou et al., 2020), which were consistent to our results. Three $\mathrm{COI}$ sequences of $O$. defensor were used in this analysis, two of which were collected from the northwest Pacific and the other one was collected from the southwest Pacific. The genetic distance was much higher (0.025 and 0.028) between the northwest Pacific and the southwest Pacific than that $(0.001)$ between two specimens from the northwest Pacific. This may be attributed to the large geographical distance, suggesting a potentially distinct population difference of $O$. defensor between the northwest and the southwest Pacific. According to the ABGD species delineation results, the interspecific distances within the genus Ophioplinthaca (0.030-0.184, average value 0.117$)$ are also comparable to previous study which suggesting that 
406 the average interspecific distances within same genus ranged from 0.056 to 0.316 (Boissin et al., 407 2017).

\section{Conclusions}

409 Three species of the genus Ophioplinthaca were recorded and described, including a new 410 species, Ophioplinthaca grandisquama n. sp., which can be easily distinguished from its congeners 411 by the shape and size of tentacle scales and disc spines, as well as radial shields. Morphological 412 characteristics of internal skeleton were also described, providing significant information for 413 future taxonomic study of this genus. Phylogenetic study based on COI supported the delimitation 414 of the new species and the other species with COI sequences available from GenBank in the genus 415 Ophioplinthaca in this study. These findings further enrich the distribution of Ophioplinthaca from 416 the seamount in the Northwest Pacific Ocean, filling the knowledge gap of benthic invertebrate in 417 the cobalt-rich area.

418

\section{Acknowledgements}

420 We thank all the scientists and crew on the RV DAYANGYIHAO and the HAILONG team for 421 their great work in the collection of the specimens. We also appreciate Dr. Lu Bo and Dr. Shen 422 Chengcheng for their help in providing species information of the corals and sponges hosting the 423 ophiuroids, Dr. Lin Shiquan for his help in making the sampling map, Dr Zhang Ruiyan for her

424 help with the genetic analysis.

\section{References}

426 Boissin E, Hoareau TB, Paulay G \& Bruggemann, JH. 2017. DNA barcoding of reef brittle stars (Ophiuroidea, Echinodermata) from the southwestern Indian Ocean evolutionary hot spot of biodiversity. Ecology and Evolution. 7(24):11197-11203.

Cherbonnier G, Sibuet M. 1972. Resultats Scientifique de la compagne Noratlante: Asterides et Ophiures. Bulletin du Museum National d'Histoire Naturell Paris 3e serie Zoologie No. 76. 102: 1333-1394.

Cho W, Shank TM. 2010. Incongruent patterns of genetic connectivity among four ophiuroid species with differing coral host specificity on North Atlantic seamounts. Marine Ecology. 31: 121-143.

Christodoulou M, O’Hara TD, Hugall AF \& Arbizu PM. 2019. Dark Ophiuroid Biodiversity in a Prospective Abyssal Mine Field. Current Biology. 29(22): 1-4 DOI: 10.1016/j.cub.2019.09.012.

Christodoulou M, O'Hara TD, Hugall AF, Khodami S \& Arbizu PM. 2020. Unexpected high abyssal

$$
\text { ophiuroid diversity in polymetallic nodule fields of the northeast pacific ocean and implications for }
$$
conservation. Biogeosciences. 17(7): 1845-1876.

Clark AH. 1949. Ophiuroidea of the Hawaiian Islands. Bulletin of the Bernice P. Bishop Museum. 195: 3133. 
441 Clark HL. 1900. The Echinoderms of Porto Rico. Bulletin of the U.S. Fisheries Commision. 20(2): 233442263.

443 Clark HL. 1911. North Pacific Ophiurans in the collection of the United States National

$444 \quad$ Museum. Smithsonian Institution United States National Museum Bulletin. 75: 1-302.

445 Clark HL. 1939. Ophiuroidea. Scient. Rep. Murray Exped. 6: 29-136.

446 Guille A. 1981. Echinodermes: Ophiurides. in: Forest, J. (Ed.) Résultats des campagnes MUSORSTOM:

447 1. Philippines (18-28 Mars 1976). Mémoires du Muséum national d'Histoire naturelle. Série A, $448 \quad$ Zoologie. 91: 413-456.

449 Hein JR, Conrad TA, Dunham RE. 2009. Seamount Characteristics and Mine-Site Model Applied to

450 Exploration- and Mining-Lease-Block Selection for Cobalt-Rich Ferromanganese Crusts. Marine Georesources and Geotechnology. 27: 160-176 DOI: 10.1080/10641190902852485.

John DD \& Clark AM. 1954. The "Rosaura" expedition. 3. The echinodermata. Bulletin of the British Museum (Natural History) Zoology. 2: 139-162, pl. 6.

Kimura M. 1980. A simple method for estimating evolutionaryrates of base substitutions through comparative studies of nucleotide sequences. Journal of Molecular Evolution. 16: 111 - 120.

Koehler R. 1897. Echinodermes recueillis par "l'Investigator" dans l'Ocean Indien. I. Les Ophiures de mer profonde. Annales des Sciences Naturelles Zoologie, series 8. 4: 277-372, pl. 5-9.

Koehler R. 1904. Ophiures de l'expédition du Siboga. Part 1. Ophiures de mer profonde. In: Weber, Siboga Expeditie. M. E.J. Brill, Leiden. 45a: 1-176.

Koehler R.1922. Ophiurans of the Philippine Seas and adjacent waters. Smithsonian Institution United States National Museum Bulletin. 100(5): 1-486.

Koehler R. 1930. Ophiures recueillies par le Docteur Th. Mortensen dans les Mers d'Australie et dans l'Archipel Malais. Papers from Dr. Th. Mortensen's Pacific Expedition 1914-16. LIV. Videnskabelige Meddelelser fra Dansk naturhistorisk Forening. 89: 1-295, 22 pl.

Litvinova NM. 1981. Brittle-stars (Ophiuroidea). Institute of Oceanology P.P. Shirshov oh the Russian Academy of Science. Moscow: 113-131.

Ljungman A. 1867. Ophiuroidea viventia huc usque cognita enumerat. Öfversigt af Kgl. VetenskapsAkademiens Förhandlingar 1866. 23(9): 303-336.

Lyman T. 1869. Preliminary report on the Ophiuridae and Astrophytidae dredged in deep water between Cuba and Florida Reef. Bulletin of the Museum of Comparative Zoology. 1: 309-354.

Lyman T. 1878. Ophiuridae and Astrophytidae of the exploring voyage of H.M.S. Challenger, under Prof. Sir Wyville Thomson, F.R.S. Part 1. Bulletin of the Museum of Comparative Zoology, Harvard University. 5: 65-168, pls 1-10.

Lyman T. 1883. Reports on the results of dredging, under the supervision of Alexander Agassiz, in the Carribbean Sea (1878-79), and on the east coast of the United States, during the summer of 1880, by the U.S. coast survey steamer "Blake", commander J.R. Bartlett, U.S.N., commanding. XX.- Report on the Ophiuroidea. Bulletin of the Museum of Comparative Zoology at Harvard. 10(6): 227-287.

Martynov A. 2010. Reassessment of the classification of the Ophiuroidea (Echinodermata), based on morphological characters. I. General character evaluation and delineation of the families Ophiomyxidae and Ophiacanthidae. Zootaxa. 2697(2697):1-154.

Mortensen T. 1933. Echinoderms of South Africa (Asteroidea and Ophiuroidea) Papers from Dr. Th. Mortensen's Pacific Expedition 1914-16. Videnskabelige Meddelelser fra Dansk naturhistorisk Forening 93. 65: 215-400. 
484

485

486

487

488

489

490

491

492

493

494

495

496

497

498

499

500

501

502

503

504

505

506

507

508

509

510

511

512

513

514

515

516

517

518

519

520

521

522

523

524

525

Na J, Chen W, Zhang D, Zhang R, Lu B, Shen C, Zhou Y \& Wang C. 2021. Morphological description and population structure of a ophiuroid species from cobalt-rich crust seamounts in the northwest Pacific: implications for marine protection under deep-sea mining. Acta Oceanological Sinica, Doi: 10.1007/s13131-020-1666-1.

Na J, Zhang D, Cheng H, Yang J, Zhang R, Chen W \& Wang C. 2019. The complete mitochondrial genome of a deep sea ophiuroid of the genus Amphiura (Ophiuroidea: Amphiuridae). Mitochondrial DNA Part B. 4(2): 3709-3710 DOI: 10.1080/23802359.2019.1679047.

Numberger-Thuy LD, Thuy B. 2020. A new bathyal ophiacanthid brittle star (Ophiuroidea: Ophiacanthidae) with Caribbean affinities from the Plio-Pleistocene of the Mediterranean. Zootaxa. 4820(1):19-30.

O’Hara TD \& Stöhr S. 2006. Deep water Ophiuroidea (Echinodermata) of New Caledonia: Ophiacanthidae and Hemieuryalidae. Tropical Deep Sea Benthos (Mémoires du Muséum national d'Histoire naturelle 193). 24: 33-141.

O'Hara TD, Rowden AA, Williams A. 2008. Cold-water coral habitats on seamounts: do they have a specialist fauna?. Diversity and distributions. 14(6): 925-934 DOI: 10.1111/j.14724642.2008.00495.x.

O’Hara TD, Hugall AF, Thuy B, Stöhr S \& Martynov AV. 2017. Restructuring higher taxonomy using broad-scale phylogenomics: The living Ophiuroidea. Molecular Phylogenetics and Evolution. 107: 415-430 DOI: 10.1016/j.ympev.2016.12.006.

O'Hara TD, Stöhr S, Hugall AF, Thuy B \& Martynov A. 2018. Morphological diagnoses of higher taxa in Ophiuroidea (Echinodermata) in support of a new classification. European Journal of Taxonomy. 2018(416).

Puillandre N, Lambert A, Brouillet S, Achaz G. 2012. ABGD, Automatic Barcode Gap Discovery for primary species delimitation. Molecular Ecology. 21 (8): 1864-1877 DOI: 10.1111/j.1365-294X.2011.05239.x.

Stamatakis A. 2014. RaxmL version 8: a tool for phylogenetic analysis and post-analysis of large phylogenies. Bioinformatics 30: 1312-1313 DOI: 10.1093/bioinformatics/btu033.

Stöhr S, O’Hara TD \& Thuy B. 2012. Global Diversity of Brittle Stars (Echinodermata: Ophiuroidea). PLOS ONE. 7 (3): e31940.

Stöhr S, O’Hara TD, Thuy B. (Eds) (2021). World Ophiuroidea Database. Ophioplinthaca Verrill, 1899. Accessed through: World Register of Marine Species at: http://www.marinespecies.org/aphia.php?p=taxdetails\&id=123581

Tamura K, Stecher G, Peterson D, Filipski A, Kumar S. 2013. Mega6: molecular evolutionary genetics analysis version 6.0. Molecular Biology \& Evolution. 30(12):2725-2729 DOI: 10.1093/molbev/mst197.

Thomson CW. 1877. The voyage of the "Challenger." The Atlantic; a preliminary account of the general results of the exploring voyage of H.M.S. "Challenger" during the year 1873 and the early part of the year 1876, Volume 1 xxix+424 pp. (Macmillan and Co.: London).

Thuy B, Stöhr S. 2011. Lateral arm plate morphology in brittle stars (Echinodermata: Ophiuroidea): New perspectives for ophiuroid micropalaeontology and classification. Zootaxa. 3013:1-47.

Thuy, B. 2013. Temporary expansion to shelf depths rather than an onshore-offshore trend: the shallowwater rise and demise of the modern deep-sea brittle star family Ophiacanthidae (Echinodermata: Ophiuroidea). European Journal of Taxonomy. 48: 1-242.

Peer) reviewing PDF | (2020:11:55728:3:0:NEW 11 May 2021) 
526 Thuy B, Stöhr S. 2016. A New Morphological Phylogeny of the Ophiuroidea (Echinodermata) Accords

527

528

529

530

531

532

533

534

535

536

537 with Molecular Evidence and Renders Microfossils Accessible for Cladistics. Plos One. 11(5): e0156140.

Verrill AE. 1899. Report on the Ophiuroidea collected by the Bahama expedition in 1893. Bulletin of the Laboratories of Natural History of the State of Iowa. 5: 1-88, pls 1-8.

Ward RD, Holmes BH \& O'Hara TD. 2008. DNA barcoding discriminates echinoderm species. Molecular Ecology Resources. 8 (6): 1202-1211 DOI: 10.1111/j.1755-0998.2008.02332.x.

Yesson C, Clark M R, Taylor M \& Rogers AD. 2011. The global distribution of seamounts based on 30second bathymetry data. Deep-Sea Research Part I. 58: 442-453 DOI: 10.1016/j.dsr.2011.02.004.

Zhang D, Lu B, Wang C, O'Hara TD. 2018. The first record of Ophioleila elegans (Echinodermata: Ophiuroidea) from a deep-sea seamount in the Northwest Pacific Ocean. Acta Oceanologica Sinica. 37 (10): 180-184 DOI: 10.1007/s13131-018-1323-0. 


\section{Figure 1}

Map of the study seamount (indicated by the small red block) in the northwest Pacific (A) and sampling sites of specimens of ophioplinthacids (B).

credit attribution: Dr. Lin Shiquan
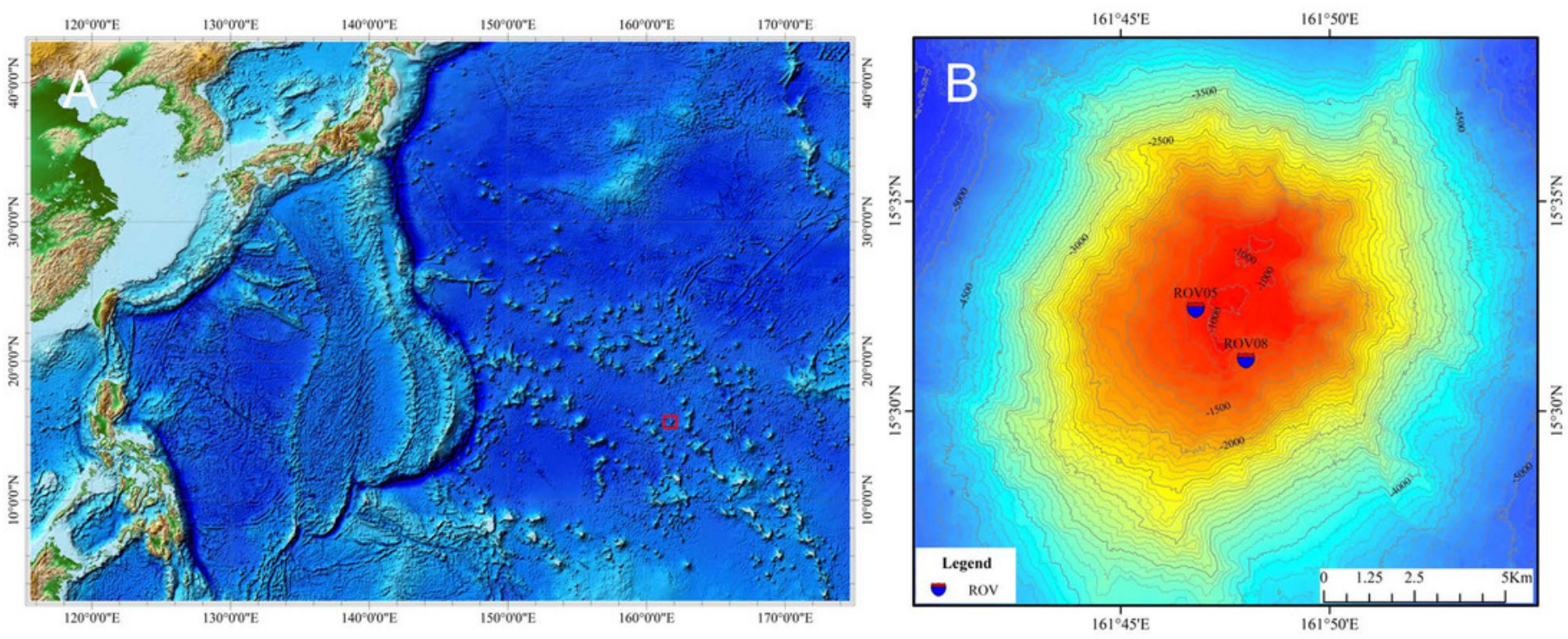


\section{Figure 2}

In situ and on board photos of Ophioplinthaca grandisquama n. sp.

(A) in situ observations, several specimens attached on a Primnoid. (B-D) photos on board.

(B) holotype (RSIO56060). (C) paratype (RSI056014).

(D) paratype (RSI056013).

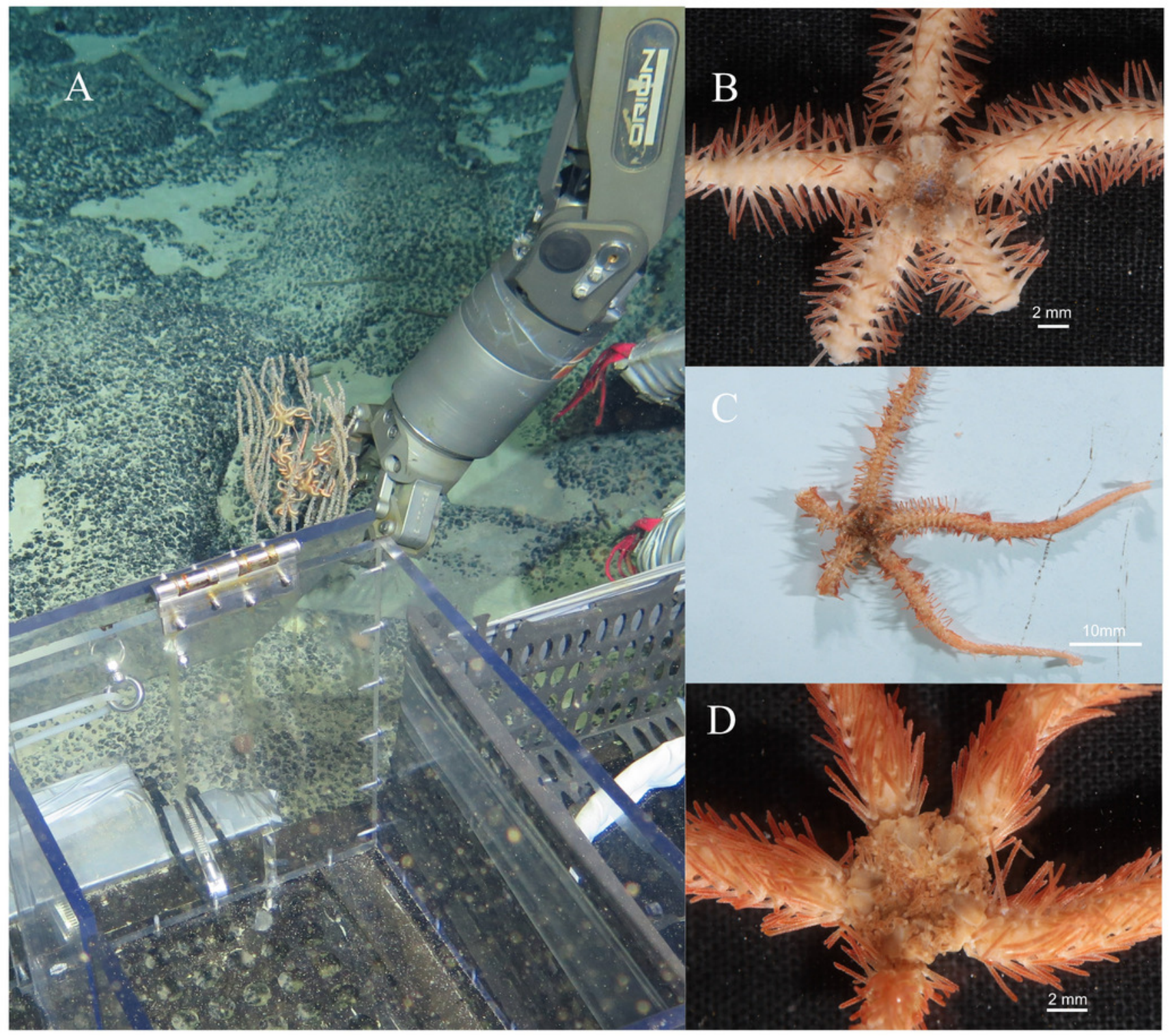




\section{Figure 3}

Morphological characters of Ophioplinthaca grandisquama n. sp. (Holotype: RSIO56060).

(A) dorsal view of disc. (B) enlarged disc spines. (C) ventral view of disc. (D) dorsal view of arm, proximal part. (E) ventral view of arm, proximal part. Abbreviations: $A D$, adoral plate; AS, arm spine; DAP, dorsal arm plate; DP, dental papillae; DS, disc spine; GS, genital slits; J, jaw; OP, lateral oral papilla; OS, oral shield; RS, radial shield; VAP, ventral arm plate; TE, tentacle; TS, tentacle scale. Scale bars: $1 \mathrm{~mm}$.

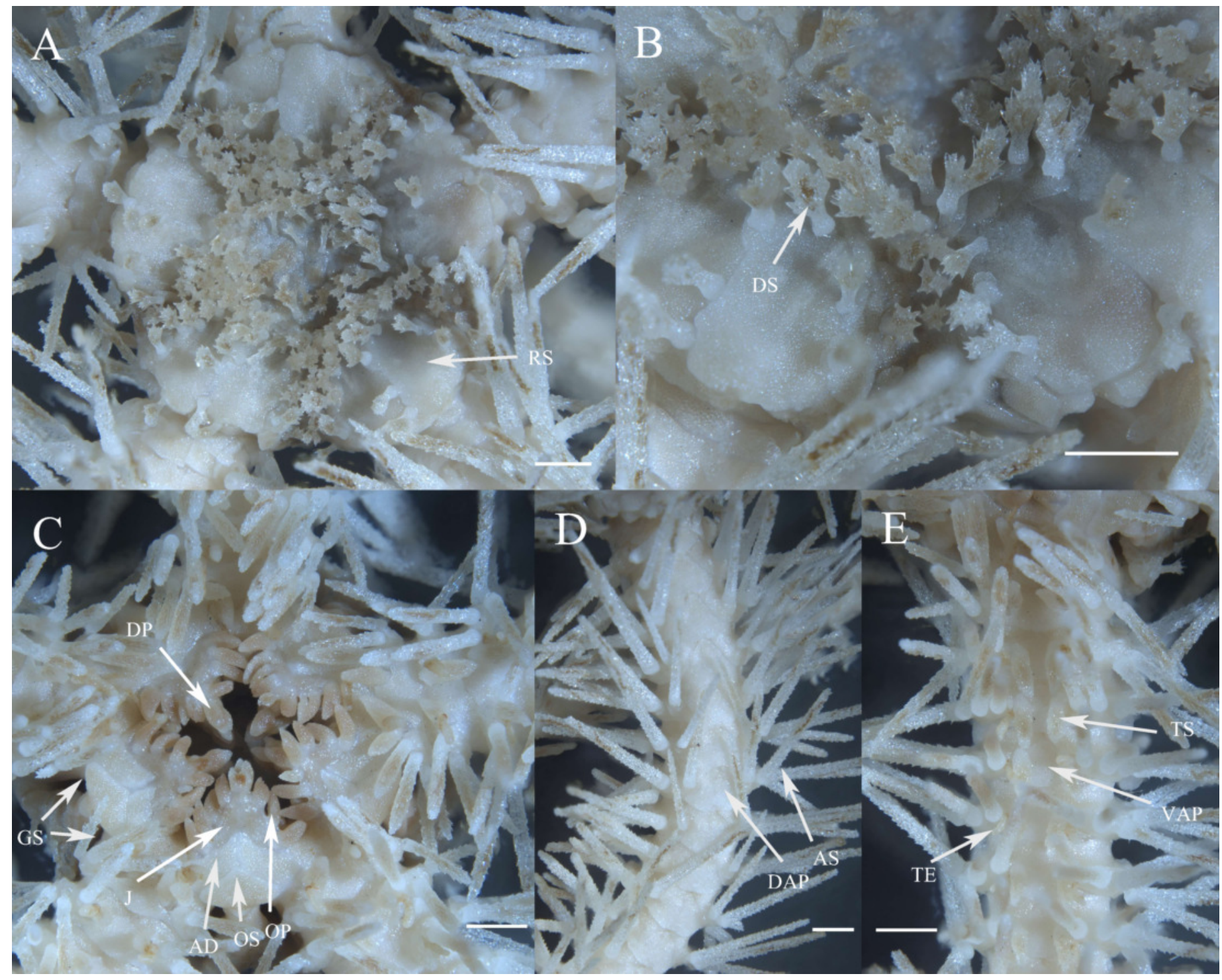




\section{Figure 4}

Morphological characters of Ophioplinthaca grandisquama n. sp. (Paratype: RSI056013, RSIO56014).

(A-B) Morphological characters of paratype RSIO56014. (A) dorsal view of disc. (B) ventral view of disc. (C-D) Morphological characters of paratype RSI056013. (C) dorsal view of disc. (D) ventral view of disc. Abbreviations: $A D$, adoral plate; $A S$, arm spine; DAP, dorsal arm plate; DP, dental papillae; DS, disc spine; GS, genital slits; J, jaw; OP, lateral oral papilla; OS, oral shield; RS, radial shield; VAP, ventral arm plate; TE, tentacle; TS, tentacle scale. Scale bars: $2 \mathrm{~mm}$. 


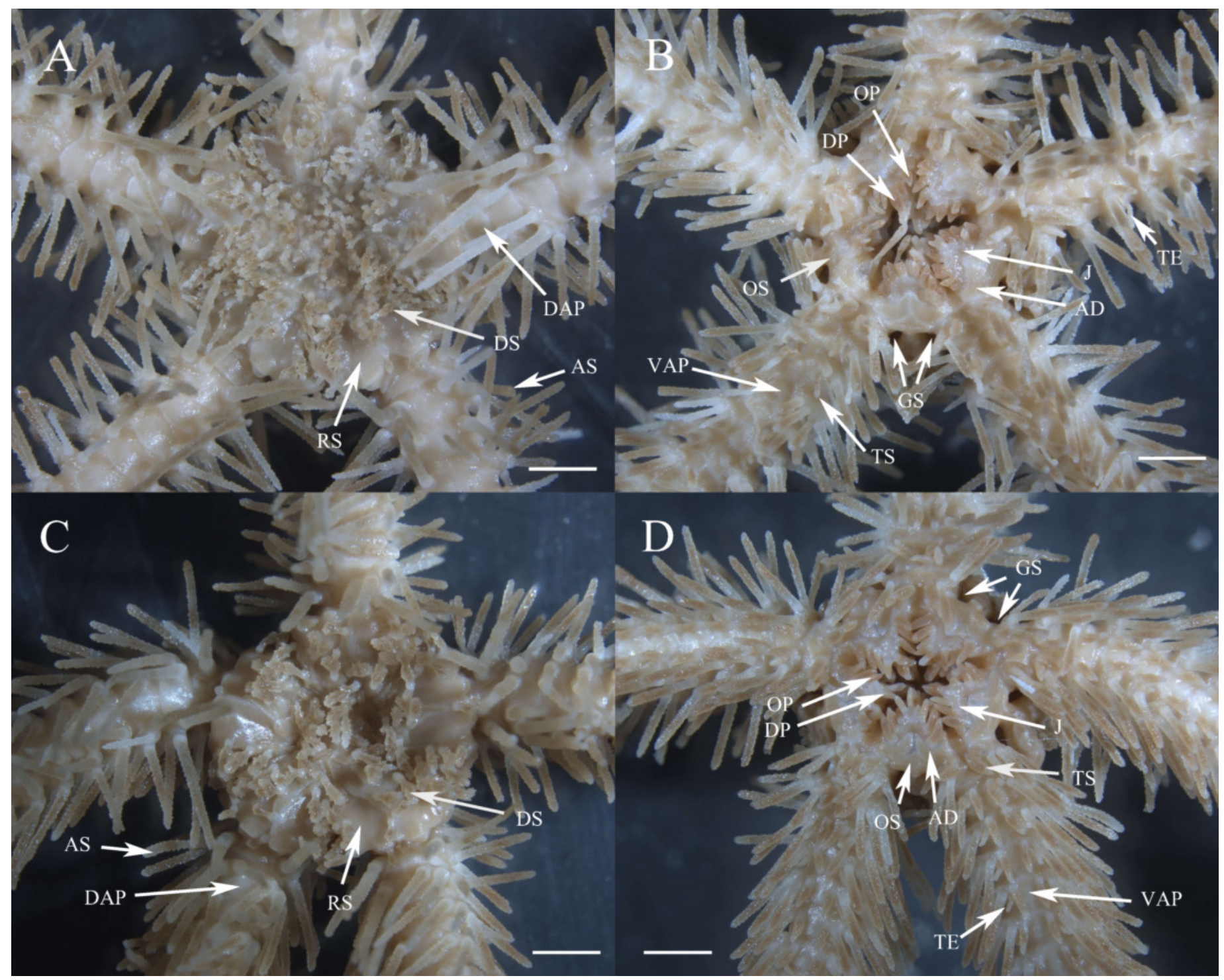




\section{Figure 5}

SEM photographs of skeletons of Ophioplinthaca grandisquama n. sp. (Paratype: RSIO56014).

(A) disc spine. (B) ventral arm plate from proximal segment, external view. (C) dorsal arm plate from proximal segment, external view. (D) ventral-most arm spine. (E) dorsal-most arm spine. (F) oral plate, abradial face. (G) oral plate, adradial face, white arrows point to oral papillae sockets and pores. (H) dental plate. (I) adradial genital plate. (J) abradial genital plate. (K) adradial genital plate, distal end. (L) radial shield, external aspect. (M) radial shield, internal aspect. (N-R) vertebrae from proximal portion of arm. (N) distal view. (O) proximal view. (P) lateral view. (Q) dorsal view. (R) ventral view. (S) external view of LAP. (T) internal view of LAP. Abbreviations: AG, aboral groove; DL, dorsal lobe; dors, dorsal; dist, distal; DW, presumable depression for water ring canal; FB, foot basin; GC, adradial genital plate condyle; k, knob; LAC, lateral ambulacral canal; LR, lateral ridge of the adradial genital plate, attachment area of the abradial genital plate; MO, muscle opening; NO, nerve opening; $p$, perforations; PD, podial basins; prox, proximal; $r$, ridge; RC, radial shield condyle; TN, tentacle notch; vent, ventral; VL, ventral lobe; WVC, water vascular canal; $Z$, zagapophyses. Scale bars: $200 \mu \mathrm{m}$. 


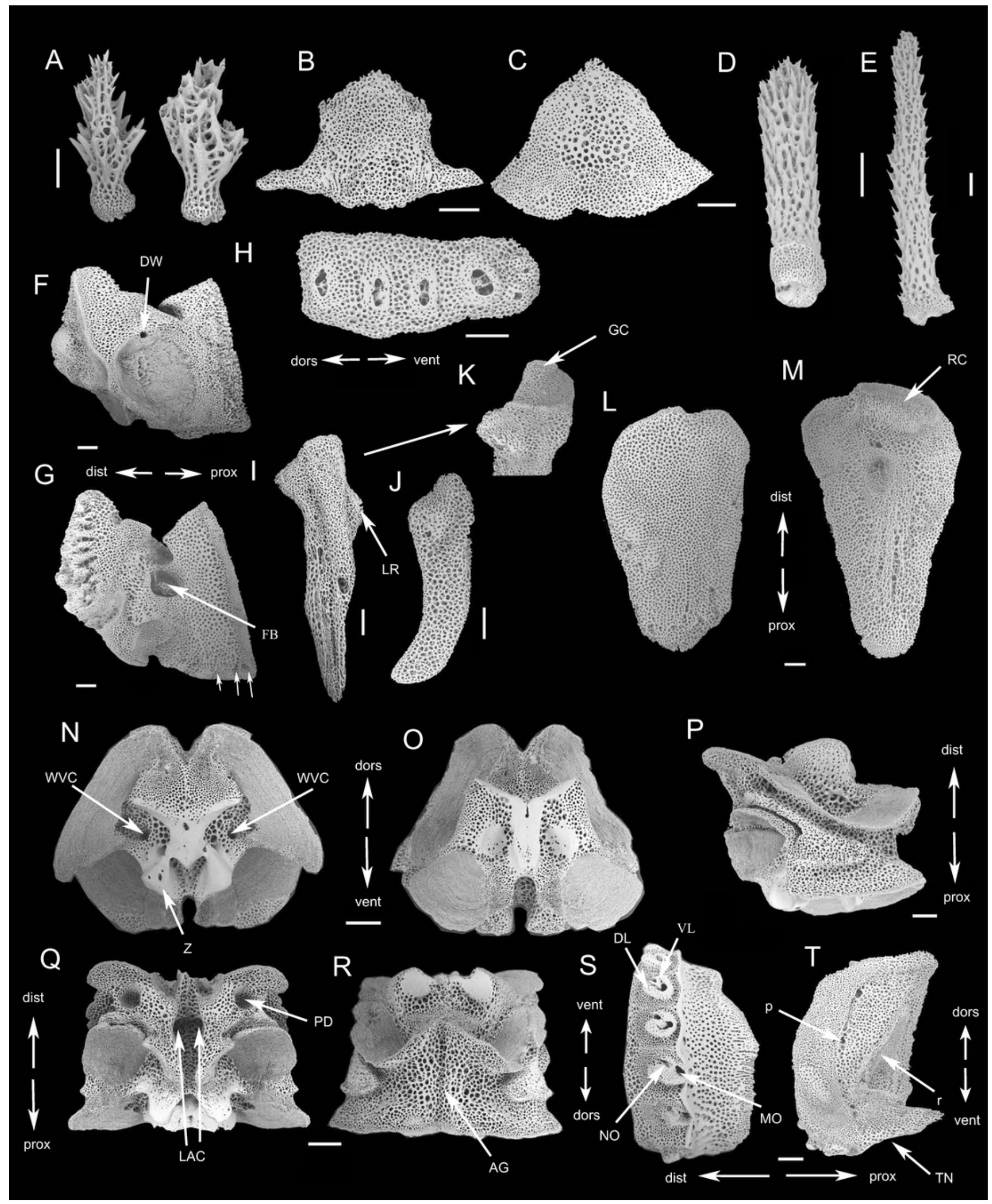




\section{Figure 6}

In situ (A) and on board (B) photos of Ophioplinthaca semele.

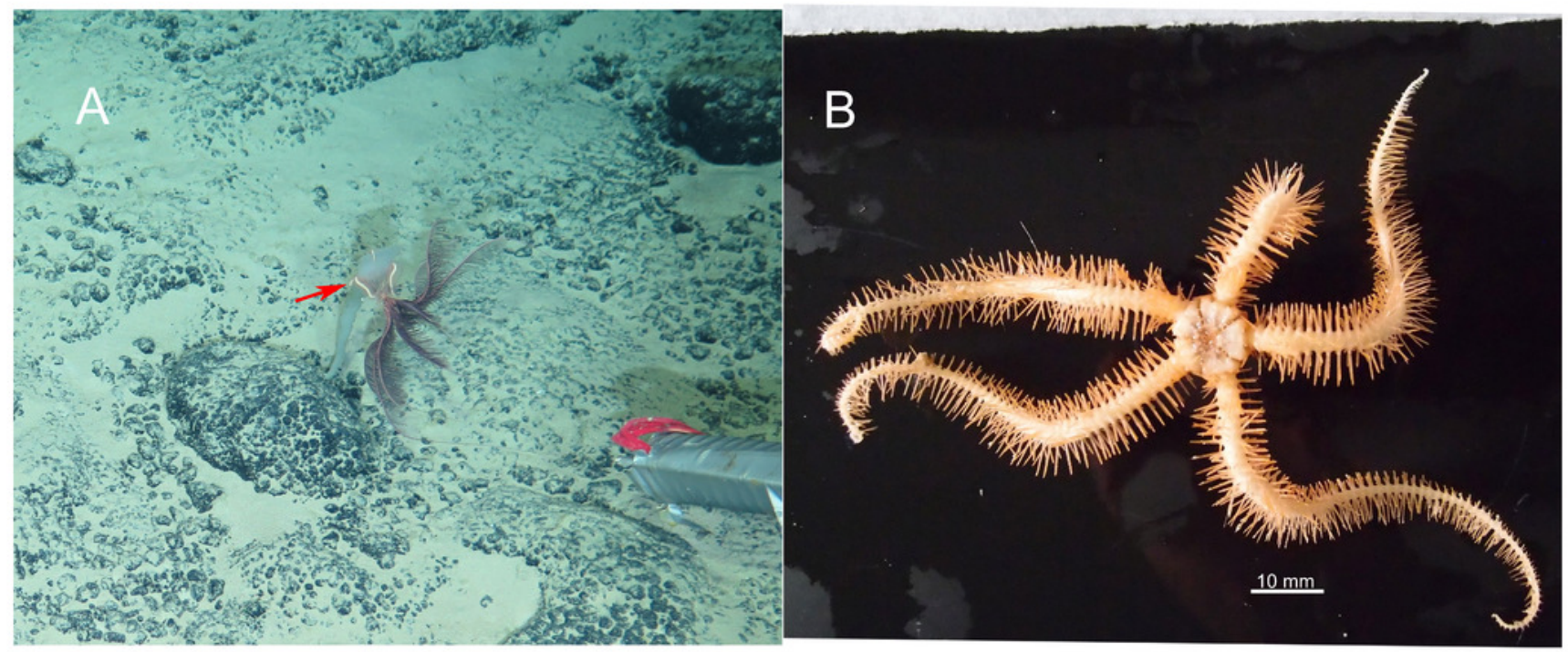




\section{Figure 7}

Morphological characters of Ophioplinthaca semele (RSIO56057).

(A) dorsal view of disc. (B) radial shields. (C) disc spines. (D) ventral view of disc. (E) dorsal view of arm, proximal part. (F) ventral view of arm, proximal part. Abbreviations: AD, adoral plate; AS, arm spine; DAP, dorsal arm plate; DP, dental papillae; DS, disc spine; GS, genital slits; J, jaw; OP, lateral oral papilla; OS, oral shield; RS, radial shield; VAP, ventral arm plate; TE, tentacle; TS, tentacle scale. Scale bars: $1 \mathrm{~mm}$ (B, C), 2 mm (A, D-F). 


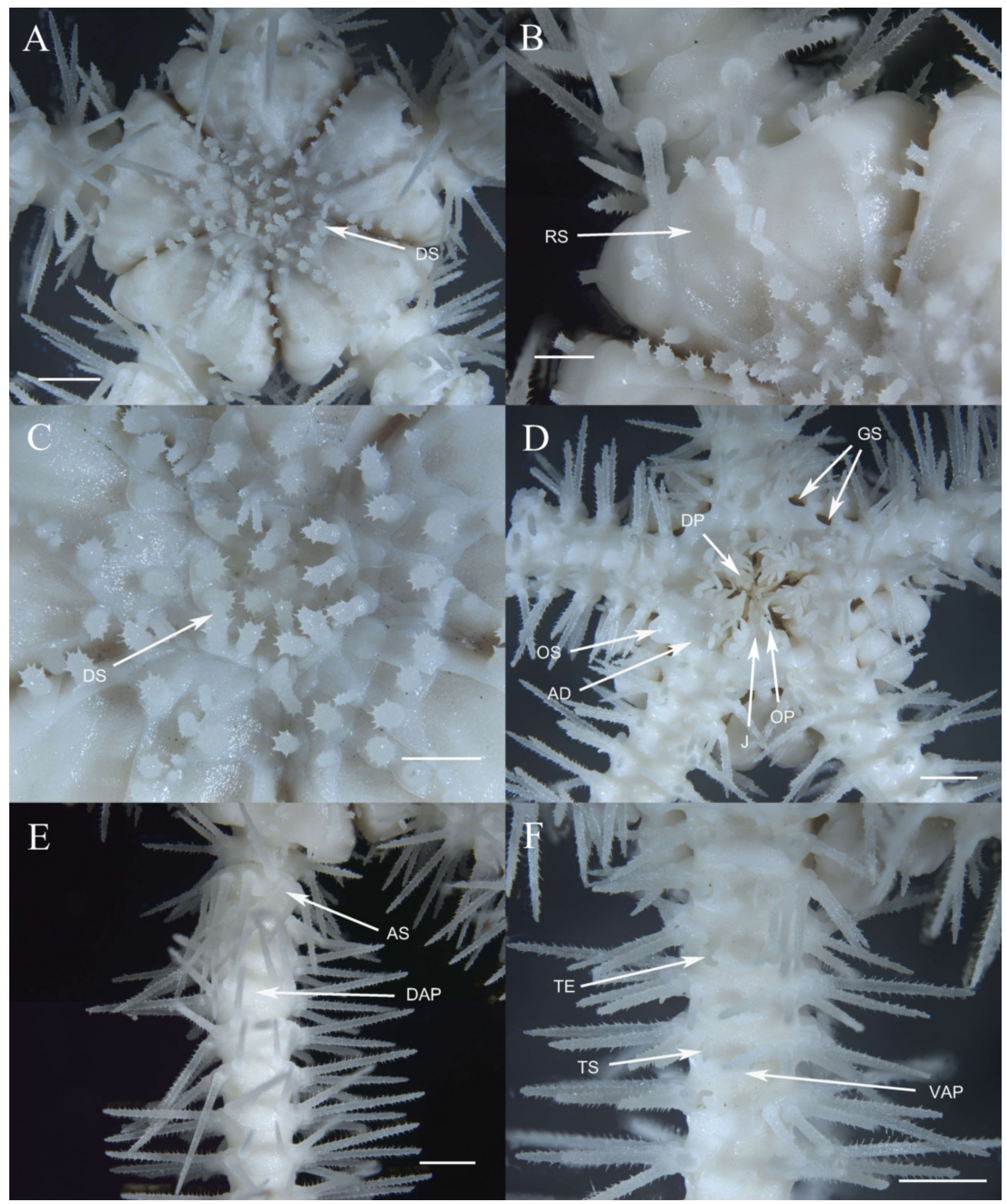




\section{Figure 8}

SEM photographs of Ophioplinthaca semele (RSIO56057).

(A) disc spine. (B) dorsal arm plate from proximal segment, external view. (C) ventral arm plate from proximal segment, external view. (D-H) vertebrae from proximal portion of arm. (D) distal view. (E) dorsal view. (F) ventral view. (G) proximal view. (H) lateral view. (I) external view of lateral arm plate. (J) internal view of lateral arm plate. Abbreviations: AG, aboral groove; DL, dorsal lobe; dors, dorsal; dist, distal; LAC, lateral ambulacral canal; MO, muscle opening; NO, nerve opening; P, perforations; PD, podial basins; prox, proximal; R, ridge; TN, tentacle notch; vent, ventral; VL, ventral lobe; WVC, water vascular canal; Z, zagapophyses. Scale bars: $200 \mu \mathrm{m}$. 


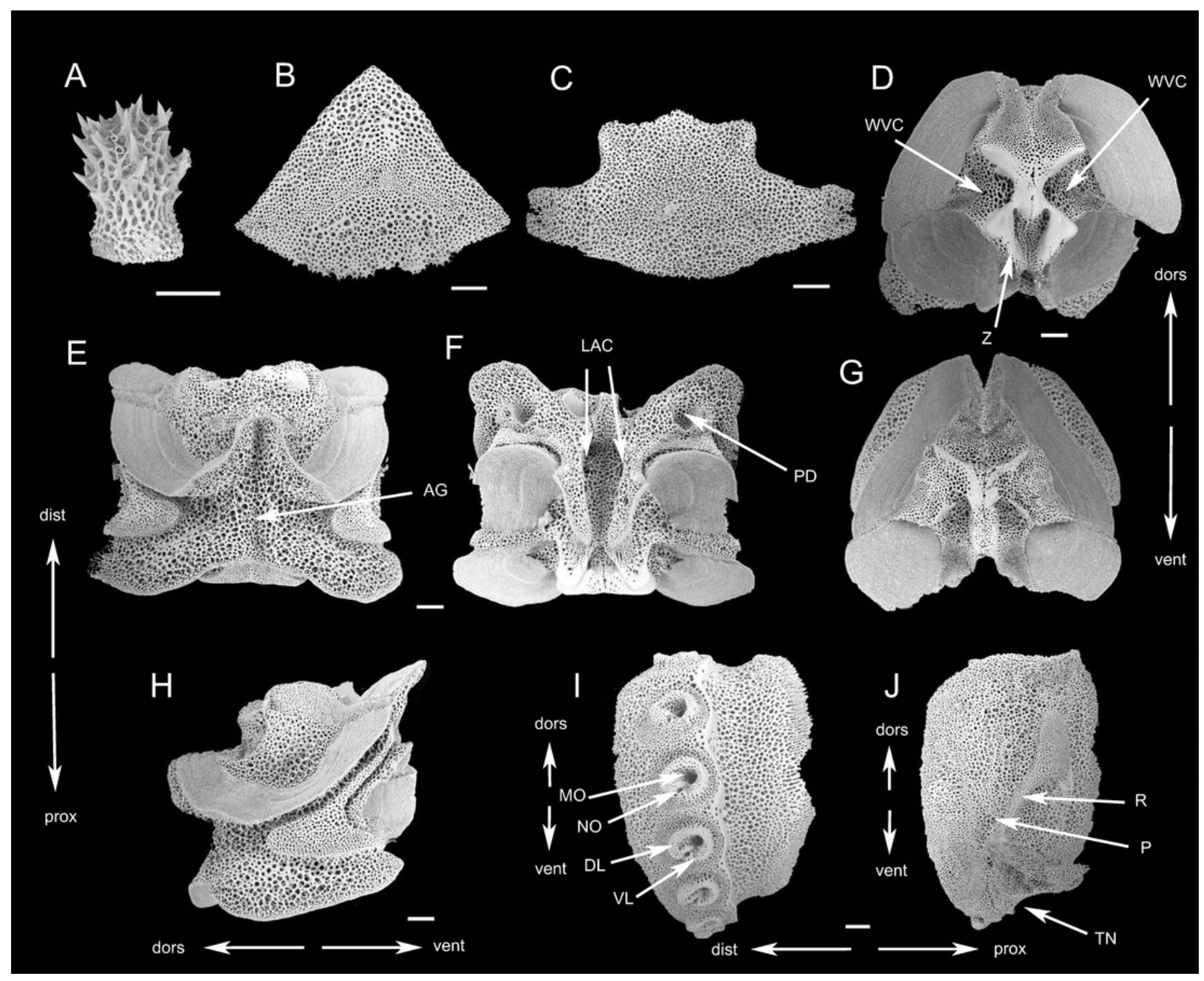




\section{Figure 9}

In situ (A) and on board (B) photos of Ophioplinthaca sp.

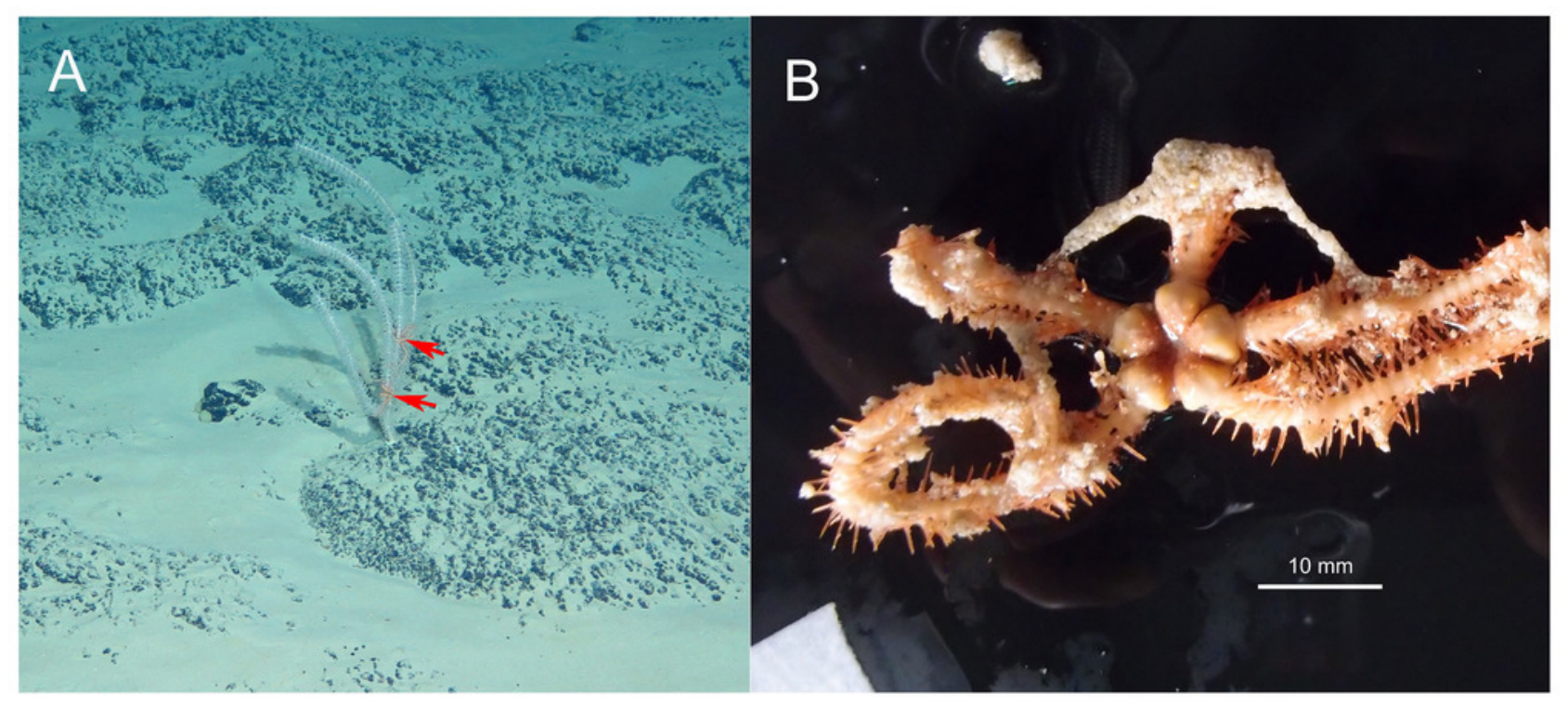




\section{Figure 10}

Morphological characters of Ophioplinthaca sp. (RSI056058).

(A) dorsal view of disc. (B) disc spines. (C) ventral view of disc. (D) dorsal view of arm, proximal part. (E) ventral view of arm, proximal part. Abbreviations: AD, adoral plate; DP, dental papillae; AS, arm spine; DAP, dorsal arm plate; DS, disc spine; GS, genital slits; J, jaw; OP, lateral oral papilla; OS, oral shield; OTS, oral tentacle scale; RS, radial shield; VAP, ventral arm plate; TE, tentacle; TS, tentacle scale. Scale bars: $2 \mathrm{~mm}$ (A, C-E), $0.2 \mathrm{~mm}$ (B).






\section{Figure 11}

SEM photographs of Ophioplinthaca sp. (RSIO56058).

(A) disc spine. (B) dorsal arm plate from proximal segment, external view. (C) ventral arm plate from proximal segment, external view. (D-H) vertebrae from proximal portion of arm. (D) proximal view. (E) dorsal view. (F) ventral view. (G) distal view. (H) lateral view. (I) external view of lateral arm plate. (J) internal view of lateral arm plate. Abbreviations: AG, aboral groove; DL, dorsal lobe; dors, dorsal; dist, distal; LAC, lateral ambulacral canal; MO, muscle opening; NO, nerve opening; P, perforations; PD, podial basins; prox, proximal; R, ridge; TN, tentacle notch; vent, ventral; VL, ventral lobe; WVC, water vascular canal; Z, zagapophyses. Scale bars: $200 \mu \mathrm{m}$. 


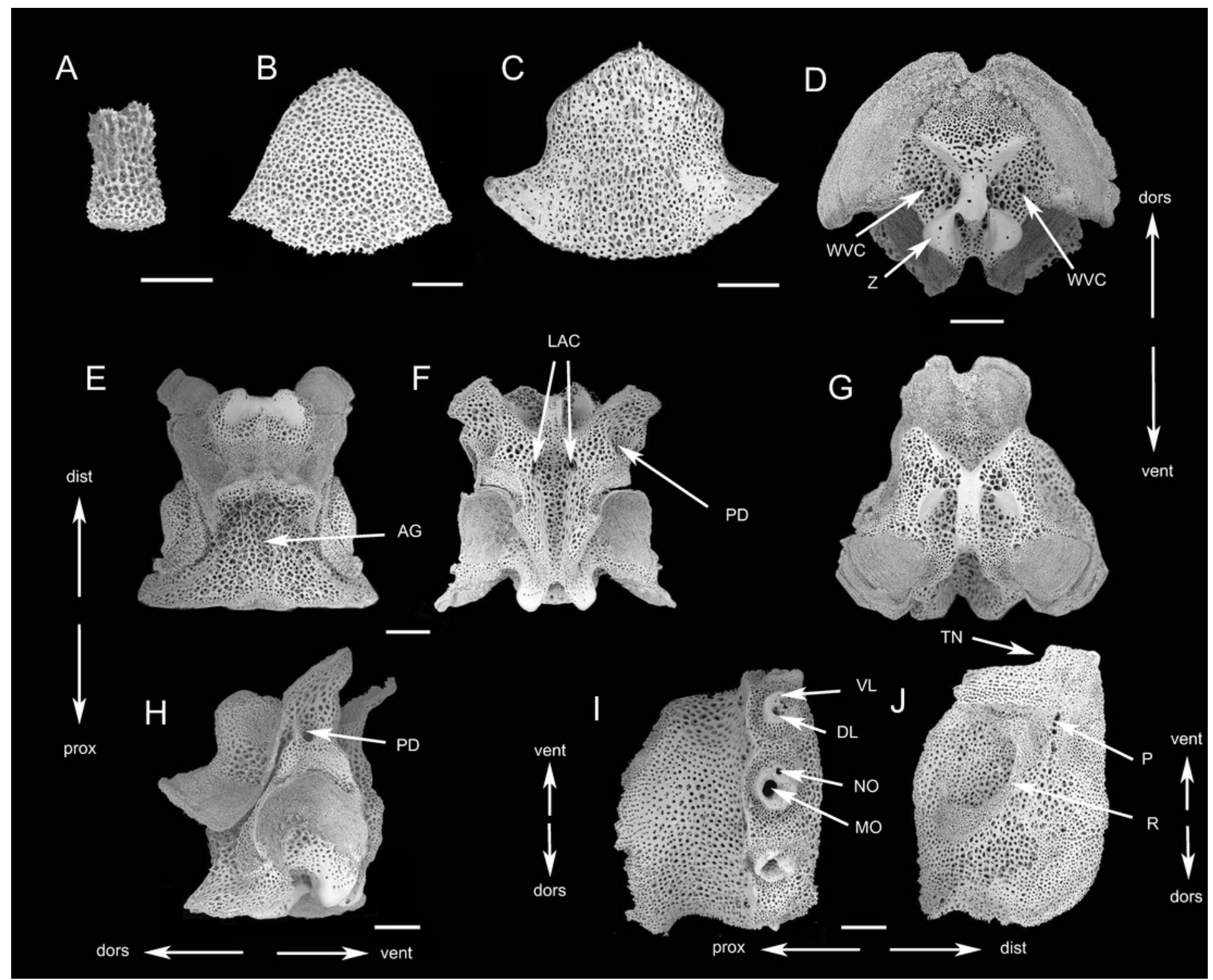




\section{Figure 12}

Lateral arm plates of four species of Ophioplinthaca from the proximal to distal segments of the arm, all shown with ventral edges upwards (in order to compare with existing research, refer to the layout format of Numberger-Thuy et al., 2020).

(A-C) Ophioplinthaca grandisquama n. sp., (A) proximal arm segments, (B) middle arm segments, (C), distal arm segments; (D-F) Ophioplinthaca semele, (D) proximal arm segments, (E) middle arm segments, (F), distal arm segments; (G-I) Ophioplinthaca sp., (G) proximal arm segments, (H) middle arm segments, (I), distal arm segments; (J-L) Ophioplinthaca defensor, (J) proximal arm segments, (K) middle arm segments, (L), distal arm segments. The vertebral articular structures marked in red, like an undivided digit 1 with a broad, nose-shaped beak. Abbreviations: be, beak; rrs, right root serif. 


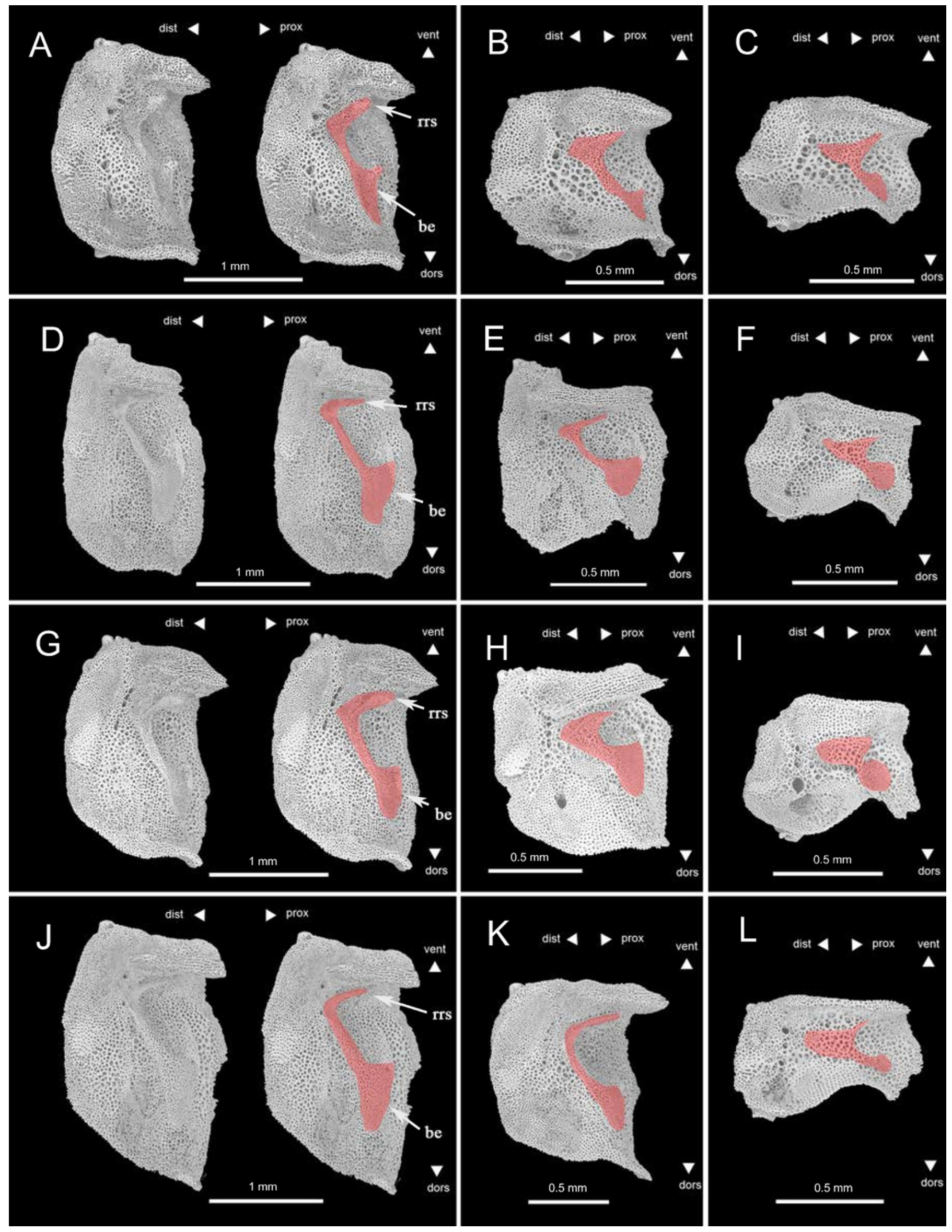


Figure 13

Maximum likelihood tree of the genus Ophioplinthaca based on COI sequences. Colored bars in red refer to MOTUs in ABGD.

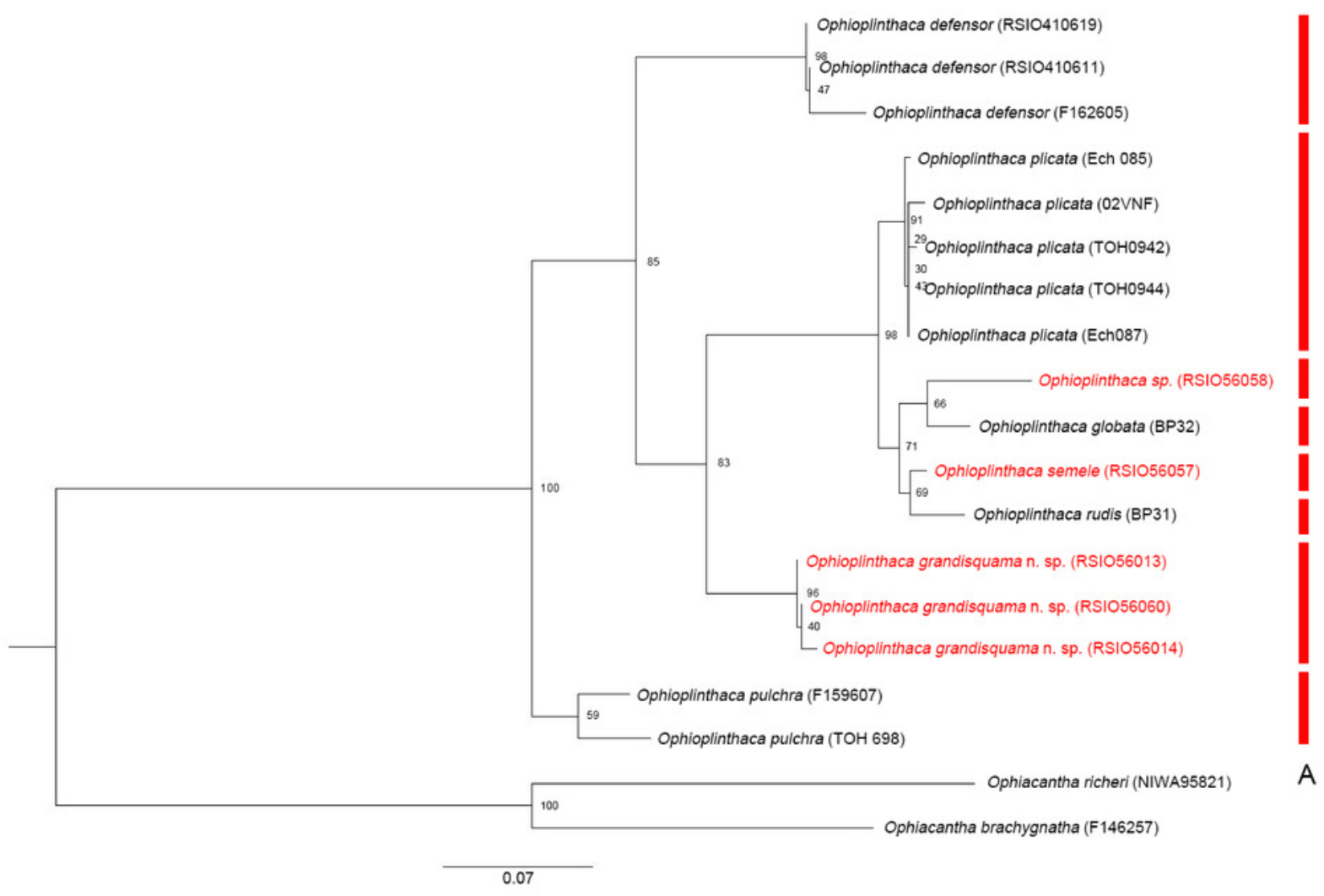


Table $\mathbf{1}$ (on next page)

Information of primers used for PCR programs. 


\begin{tabular}{ll}
\hline Prime & Sequence \\
\hline Oph-COI-F & TTTCAACTAATCAYAAGGAYATWGG \\
Oph-COI-R & CTTCAGGRTGWCCRAARAAYCA \\
\hline LCO1490 & GGTCAACAAATCATAAAGATATTGG \\
HCO2198 & TAAACTTCAGGGTGACCAAAAAATCA \\
\hline
\end{tabular}

1 


\section{Table 2 (on next page)}

COI sequence data used in phylogenetic analysis.

MV - Museums Victoria, Australia; NIWA - National Institute of Water and Atmospheric Research, New Zealand; RSIO - Second Institute of Oceanology, China. 


\begin{tabular}{|l|l|l|}
\hline Taxa & $\begin{array}{l}\text { Museum registration } \\
\text { number }\end{array}$ & $\begin{array}{l}\text { GenBank accession number/ } \\
\text { BOLD sequence ID }\end{array}$ \\
\hline Ophioplinthaca grandisquama n. sp. & RSIO56060 & MW284982 \\
\hline Ophioplinthaca grandisquama n. sp. & RSIO56013 & MW284978 \\
\hline Ophioplinthaca grandisquama n. sp. & RSIO56014 & MW284979 \\
\hline Ophioplinthaca semele & RSIO56057 & MW284980 \\
\hline Ophioplinthaca sp. & RSIO56058 & MW284981 \\
\hline Ophioplinthaca pulchra & MV F159608 & HM400467 \\
\hline Ophioplinthaca pulchra & MV F159607 & KU895136 \\
\hline Ophioplinthaca defensor & MV F162605 & ECHOZ371-10.COI-5P \\
\hline Ophioplinthaca defensor & RSIO410611 & MT025802 \\
\hline Ophioplinthaca defensor & RSIO410619 & MT025808 \\
\hline Ophioplinthaca globata & MNHN BP32 & KU895134 \\
\hline Ophioplinthaca rudis & MNHN BP31 & KU895135 \\
\hline Ophioplinthaca plicata & MV F144759 & EU869990 \\
\hline Ophioplinthaca plicata & MV F144758 & EU869989 \\
\hline Ophioplinthaca plicata & MV F188868 & KU895133 \\
\hline Ophioplinthaca plicata & MV F144757 & ECHOZ372-10.COI-5P \\
\hline Ophioplinthaca plicata & MV F144764 & ECHOZ374-10.COI-5P \\
\hline Ophiacantha richeri & NIWA5821 & KU895387 \\
\hline Ophiacantha brachygnatha & MV F146257 & KU895386 \\
\hline & & \\
\hline
\end{tabular}


Table 3(on next page)

Comparison of of key morphological characters among species from the genus Ophioplinthaca, based on literature 


\begin{tabular}{|c|c|c|c|c|c|}
\hline Species & Disc spines & $\begin{array}{l}\text { Size of radial } \\
\text { shields }\end{array}$ & $\begin{array}{lll}\begin{array}{l}\text { Position of } \\
\text { shields }\end{array} & & \\
\end{array}$ & Shape of tentacle scale & Reference \\
\hline $\begin{array}{l}\text { Ophioplinthaca } \\
\text { abyssalis }\end{array}$ & $\begin{array}{l}\text { elongate and conical granules, } \\
\text { smooth }\end{array}$ & $\begin{array}{l}1 / 3 \text { d.d., } 3 \text { times as } \\
\text { long as wide }\end{array}$ & $\begin{array}{l}\text { contiguous or just } \\
\text { separate distally, } \\
\text { sunken }\end{array}$ & conical and pointed & $\begin{array}{l}\text { Cherbonnier } \\
\text { Sibuet, } 1972\end{array}$ \\
\hline $\begin{array}{l}\text { Ophioplinthaca } \\
\text { amezianeae }\end{array}$ & $\begin{array}{l}\text { tall and slender spines, rounded } \\
\text { base terminating in } 2-3 \text { small } \\
\text { thorns }\end{array}$ & $\begin{array}{l}1 / 6 \text { d.d., } 2 \text { times as } \\
\text { long as wide }\end{array}$ & Separated & long and spiniform & $\begin{array}{l}\text { O’Hara \& Stöhr, } \\
2006\end{array}$ \\
\hline $\begin{array}{l}\text { Ophioplinthaca } \\
\text { athena }\end{array}$ & $\begin{array}{l}\text { elongate conical granules, with } \\
\text { a few radiating spinules at the } \\
\text { end }\end{array}$ & $\begin{array}{l}1 / 3 \text { d.d., } 4 \text { times as } \\
\text { long as wide }\end{array}$ & contiguous distally & oval to slender & Clark, 1949 \\
\hline $\begin{array}{l}\text { Ophioplinthaca } \\
\text { bythiaspis }\end{array}$ & $\begin{array}{l}\text { spherical to conical to } \\
\text { cylindrical granules, with a few } \\
\text { small terminal thorns }\end{array}$ & $\begin{array}{l}\text { 1/3-1/4 d.d., } 4 \text { times } \\
\text { as long as wide }\end{array}$ & separated, sunken & oval to bottle-shaped & $\begin{array}{l}\text { Clark H.L., 1911; } \\
\text { O’Hara \& Stöhr, } \\
2006\end{array}$ \\
\hline $\begin{array}{l}\text { Ophioplinthaca } \\
\text { carduus }\end{array}$ & $\begin{array}{l}\text { small cylindrical granules, with } \\
\text { a crown of thorns at the end }\end{array}$ & $\begin{array}{l}1 / 4 \text { d.d., } 2 \text { times as } \\
\text { long as wide }\end{array}$ & Separated & $\begin{array}{l}\text { conical and pointed, } \\
\text { with one or more side } \\
\text { thorns }\end{array}$ & Lyman, 1878 \\
\hline $\begin{array}{l}\text { Ophioplinthaca } \\
\text { chelys }\end{array}$ & $\begin{array}{l}\text { short and blunt stumps, usually } \\
\text { smooth, which also present over } \\
\text { each arm }\end{array}$ & $\begin{array}{l}1 / 3-1 / 4 \text { d.d., } 4-5 \\
\text { times as long as } \\
\text { wide }\end{array}$ & $\begin{array}{l}\text { Separated, deeply } \\
\text { sunken }\end{array}$ & $\begin{array}{l}\text { thick and pointed, } \\
\text { flattened, } \\
\text { smooth }\end{array}$ & Thomson, 1877 \\
\hline $\begin{array}{l}\text { Ophioplinthaca } \\
\text { citata }\end{array}$ & $\begin{array}{l}\text { small and cylindrical stumps, } \\
\text { with a terminal crown of thorns }\end{array}$ & $\begin{array}{l}\text { 1/4 d.d., } 3-4 \text { times as } \\
\text { long as wide }\end{array}$ & separated, sunken & oval to elliptical & $\begin{array}{l}\text { Koehler, 1904; } \\
\text { O’Hara \& Stöhr, } \\
2006\end{array}$ \\
\hline
\end{tabular}




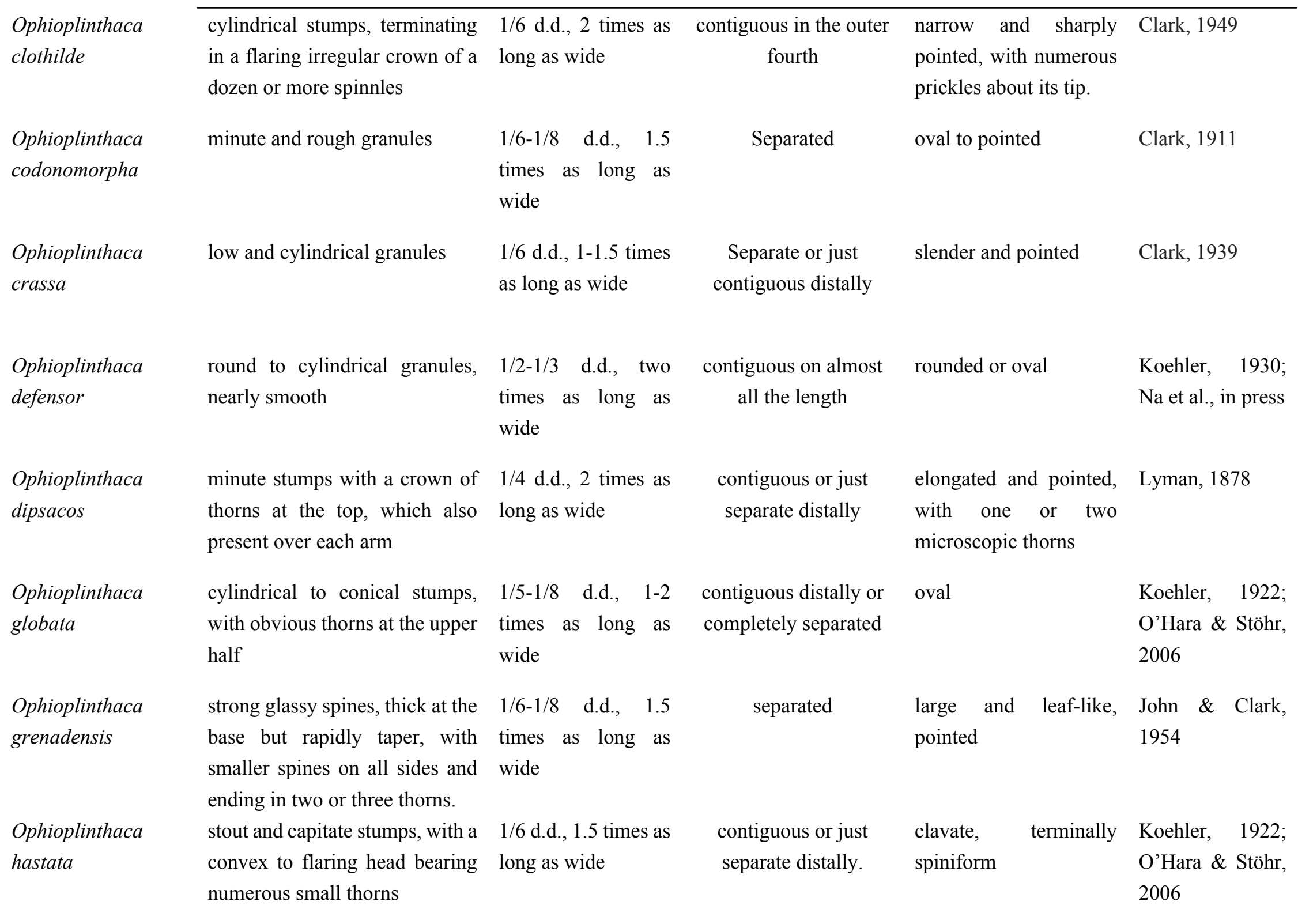




\begin{tabular}{|c|c|c|c|c|c|}
\hline & & & & & \\
\hline $\begin{array}{l}\text { Ophioplinthaca } \\
\text { incisa }\end{array}$ & $\begin{array}{l}\text { conical to cylindrical stumps, } \\
\text { smooth }\end{array}$ & $\begin{array}{l}1 / 4 \text { d.d., } 2 \text { times as } \\
\text { long as wide }\end{array}$ & $\begin{array}{l}\text { contiguous distally, a } \\
\text { little sunken }\end{array}$ & oval and thickened & Lyman, 1883 \\
\hline $\begin{array}{l}\text { Ophioplinthaca } \\
\text { laudator }\end{array}$ & $\begin{array}{l}\text { thin and elongated stumps, with } \\
\text { four to five divergent and } \\
\text { pointed thorns at the top }\end{array}$ & $\begin{array}{l}\text { 1/4-1/6 d.d., } 2 \text { times } \\
\text { as long as wide }\end{array}$ & $\begin{array}{l}\text { contiguous distally, a } \\
\text { little sunken }\end{array}$ & elongated and pointed & Koehler, 1930 \\
\hline $\begin{array}{l}\text { Ophioplinthaca } \\
\text { lithosora }\end{array}$ & $\begin{array}{l}\text { low and cylindrical stump, with } \\
\text { two to six small thorns near the } \\
\text { top }\end{array}$ & $\begin{array}{l}1 / 4 \text { d.d., } 3 \text { times as } \\
\text { long as wide }\end{array}$ & $\begin{array}{l}\text { Separated, a little } \\
\text { sunken }\end{array}$ & $\begin{array}{l}\text { long and rounded at tip } \\
\text { or pointed }\end{array}$ & Clark, 1911 \\
\hline $\begin{array}{l}\text { Ophioplinthaca } \\
\text { manillae }\end{array}$ & $\begin{array}{l}\text { elongated and cylindrical } \\
\text { stump, terminated by several } \\
\text { sharp points forming a crown, or } \\
\text { divided into three digits }\end{array}$ & $\begin{array}{l}1 / 4-1 / 6 \text { d.d., as long } \\
\text { as wide }\end{array}$ & contiguous distal half & $\begin{array}{l}\text { pointed and elongate, } \\
\text { more } \\
\text { denticulate }\end{array}$ & Guille, 1981 \\
\hline $\begin{array}{l}\text { Ophioplinthaca } \\
\text { miranda }\end{array}$ & $\begin{array}{l}\text { rounded granules, base narrows } \\
\text { in a very short pedicle, trimmed } \\
\text { with fine pointed asperities }\end{array}$ & $\begin{array}{l}1 / 6 \text { d.d., } 2 \text { times as } \\
\text { long as wide }\end{array}$ & $\begin{array}{l}\text { contiguous in the outer } \\
\text { fourth }\end{array}$ & small and oval & Koehler, 1904 \\
\hline $\begin{array}{l}\text { Ophioplinthaca } \\
\text { monitor }\end{array}$ & $\begin{array}{l}\text { short and bowl-shaped stumps, } \\
\text { with an expanded apex covered } \\
\text { in sharp thorns }\end{array}$ & $\begin{array}{l}1 / 4 \text { d.d., } 2.5 \text { times } \\
\text { longer }\end{array}$ & $\begin{array}{l}\text { widely separated, } \\
\text { sunken }\end{array}$ & oval to spongy & $\begin{array}{l}\text { Koehler, 1930; } \\
\text { O’Hara \& Stöhr, } \\
2006\end{array}$ \\
\hline $\begin{array}{l}\text { Ophioplinthaca } \\
\text { papillosa }\end{array}$ & $\begin{array}{l}\text { elongated and cylindrical } \\
\text { stump, terminated by } 3-6 \text { thorns }\end{array}$ & $\begin{array}{l}1 / 3 \text { d.d., } 2 \text { times as } \\
\text { long as wide }\end{array}$ & broadly contiguous & flat and pointed & Clark, 1939 \\
\hline $\begin{array}{l}\text { Ophioplinthaca } \\
\text { plicata }\end{array}$ & $\begin{array}{l}\text { conical to cylindrical to capitate } \\
\text { granules, finely rugose or rarely } \\
\text { with a few thorns }\end{array}$ & $\begin{array}{l}1 / 3-1 / 4 \text { d.d., } 2-2.5 \\
\text { times as long as } \\
\text { wide }\end{array}$ & contiguous distally & $\begin{array}{l}\text { erect, curved inwards } \\
\text { with a pointed to } \\
\text { rounded tip }\end{array}$ & $\begin{array}{l}\text { Lyman, 1878; } \\
\text { O’Hara \& Stöhr, } \\
2006\end{array}$ \\
\hline
\end{tabular}




\begin{tabular}{|c|c|c|c|c|c|}
\hline $\begin{array}{l}\text { Ophioplinthaca } \\
\text { pulchra }\end{array}$ & $\begin{array}{l}\text { spherical to capitate stumps, } \\
\text { nearly smooth }\end{array}$ & $\begin{array}{l}1 / 3 \text { d.d., } 2-2.5 \text { times } \\
\text { as long as wide }\end{array}$ & $\begin{array}{l}\text { Separate or contiguous } \\
\text { distally }\end{array}$ & Small and conical & $\begin{array}{l}\text { Koehler, 1904; } \\
\text { O’Hara \& Stöhr, } \\
2006\end{array}$ \\
\hline $\begin{array}{l}\text { Ophioplinthaca } \\
\text { rudis }\end{array}$ & $\begin{array}{l}\text { long and slender spines, needle- } \\
\text { like, smooth to finely serrate }\end{array}$ & $\begin{array}{l}1 / 3 \text { d.d., } 1-2 \text { times as } \\
\text { long as wide }\end{array}$ & $\begin{array}{l}\text { Separate or contiguous } \\
\text { distally }\end{array}$ & bottle-shaped to pointed & $\begin{array}{l}\text { Koehler, 1897; } \\
\text { O’Hara \& Stöhr, } \\
2006\end{array}$ \\
\hline $\begin{array}{l}\text { Ophioplinthaca } \\
\text { sarsii }\end{array}$ & $\begin{array}{l}\text { short and stout stump, smooth, } \\
\text { which also present over each } \\
\text { arm }\end{array}$ & $\begin{array}{l}2 \text { times as long as } \\
\text { wide }\end{array}$ & $\begin{array}{l}\text { widely separated, } \\
\text { sunken }\end{array}$ & $\begin{array}{l}\text { stout and pointed, } \\
\text { flattened, cloven or } \\
\text { jagged on the edges }\end{array}$ & Lyman, 1878 \\
\hline $\begin{array}{l}\text { Ophioplinthaca } \\
\text { semele }\end{array}$ & $\begin{array}{l}\text { thick and swollen cylindrical } \\
\text { stumps, with a few short and } \\
\text { flaring thorns at the top }\end{array}$ & $\begin{array}{l}\text { more than } 1 / 4 \text { d.d., } \\
2.5-3 \text { times as long } \\
\text { as wide }\end{array}$ & $\begin{array}{l}\text { contiguous in the outer } \\
\text { third }\end{array}$ & spinous, more pointed & Clark, 1949 \\
\hline $\begin{array}{l}\text { Ophioplinthaca } \\
\text { sexradia }\end{array}$ & conical granules, smooth & $\begin{array}{l}1 / 2 \text { d.d., } 2-3 \text { times as } \\
\text { long as wide }\end{array}$ & contiguous distally & small and oval & Mortensen, 1933 \\
\hline $\begin{array}{l}\text { Ophioplinthaca } \\
\text { spinissima }\end{array}$ & small and thorny stumps & $\begin{array}{l}\text { 1/3-1/4 d.d., } 2 \text { times } \\
\text { as long as wide }\end{array}$ & & large and pointed & Clark, 1900 \\
\hline $\begin{array}{l}\text { Ophioplinthaca } \\
\text { tylota }\end{array}$ & $\begin{array}{l}\text { knob-like tubercle, typically } \\
\text { bud-like with a short stalk which } \\
\text { merges into the ellipsoid } \\
\text { tubercle itself }\end{array}$ & $\begin{array}{l}1 / 4 \text { d.d., } 3 \text { times as } \\
\text { long as wide }\end{array}$ & contact and overlaps & flat and pointed, thorny & Clark, 1939 \\
\hline $\begin{array}{l}\text { Ophioplinthaca } \\
\text { weberi }\end{array}$ & no & $\begin{array}{l}1 / 3 \text { d.d., } 2 \text { times as } \\
\text { long as wide }\end{array}$ & $\begin{array}{l}\text { contiguous in the outer } \\
\text { half }\end{array}$ & small and oval & Koehler, 1904 \\
\hline
\end{tabular}




$\begin{array}{llll}\text { Ophioplinthaca } & \text { long and stout spines, capitate } 1 / 4 \text { d.d., } 1.5 \text { times as } & \text { contiguous distally } & \begin{array}{l}\text { long and thorny, with a Present study } \\ \text { grandisquama } \mathrm{n} . \mathrm{sp} .\end{array} \\ & \text { with typically elongate to long as wide } & \text { trunk base tapering into } \\ & \text { flaring head bearing numerous } & \text { a blunt point }\end{array}$


Table 4 (on next page)

The genetic distance of $\mathrm{COI}$ gene (K2P) of Ophioplinthaca. 


\begin{tabular}{|c|c|c|c|c|c|c|c|c|c|c|c|c|c|c|c|c|c|c|}
\hline & 1 & 2 & 3 & 4 & 5 & 6 & 7 & 8 & 9 & 10 & 11 & 12 & 13 & 14 & 15 & 16 & 17 & 18 \\
\hline \multicolumn{19}{|l|}{1 Ophioplinthaca pulchra (MV F159607) } \\
\hline 2 Ophioplinthaca pulchra (MV F159608) & 0.049 & & & & & & & & & & & & & & & & & \\
\hline 3 Ophioplinthaca sp. (RSIO56058) & 0.157 & 0.184 & & & & & & & & & & & & & & & & \\
\hline 4 Ophioplinthaca rudis (MNHN BP31) & 0.160 & 0.176 & 0.078 & & & & & & & & & & & & & & & \\
\hline 5 Ophioplinthaca semele (RSIO56057) & 0.160 & 0.156 & 0.060 & 0.032 & & & & & & & & & & & & & & \\
\hline 6 Ophioplinthaca plicata (MV F144759) & 0.140 & 0.148 & 0.084 & 0.051 & 0.036 & & & & & & & & & & & & & \\
\hline 7 Ophioplinthaca plicata (MV F188868) & 0.153 & 0.160 & 0.085 & 0.055 & 0.042 & 0.012 & & & & & & & & & & & & \\
\hline 8 Ophioplinthaca plicata (MV F144757) & 0.134 & 0.145 & 0.086 & 0.050 & 0.030 & 0.008 & 0.009 & & & & & & & & & & & \\
\hline 9 Ophioplinthaca plicata (MV F144758) & 0.137 & 0.155 & 0.084 & 0.050 & 0.036 & 0.005 & 0.008 & 0.004 & & & & & & & & & & \\
\hline 10 Ophioplinthaca globata (MNHN BP32) & 0.146 & 0.150 & 0.063 & 0.057 & 0.050 & 0.057 & 0.051 & 0.032 & 0.053 & & & & & & & & & \\
\hline 11 Ophioplinthaca plicata (MV F144764) & 0.125 & 0.149 & 0.092 & 0.054 & 0.031 & 0.005 & 0.003 & 0.003 & 0.000 & 0.000 & & & & & & & & \\
\hline 12 O. grandisquama n. sp.（RSIO56014） & 0.123 & 0.144 & 0.136 & 0.125 & 0.108 & 0.110 & 0.115 & 0.110 & 0.110 & 0.107 & 0.103 & & & & & & & \\
\hline 13 O. grandisquama n. sp.（RSIO56013） & 0.112 & 0.135 & 0.141 & 0.129 & 0.111 & 0.114 & 0.116 & 0.117 & 0.114 & 0.127 & 0.107 & 0.009 & & & & & & \\
\hline 14 O. grandisquama n. sp.（RSIO56060） & 0.119 & 0.148 & 0.152 & 0.127 & 0.108 & 0.113 & 0.118 & 0.120 & 0.115 & 0.115 & 0.117 & 0.007 & 0.002 & & & & & \\
\hline 15 Ophioplinthaca defensor (MV F162605) & 0.111 & 0.147 & 0.180 & 0.174 & 0.138 & 0.149 & 0.152 & 0.153 & 0.153 & 0.097 & 0.152 & 0.096 & 0.091 & 0.119 & & & & \\
\hline 16 Ophioplinthaca defensor (RSIO410611) & 0.122 & 0.131 & 0.176 & 0.159 & 0.140 & 0.148 & 0.153 & 0.137 & 0.146 & 0.151 & 0.137 & 0.104 & 0.103 & 0.121 & 0.025 & & & \\
\hline 17 Ophioplinthaca defensor (RSIO410619) & 0.119 & 0.129 & 0.174 & 0.156 & 0.137 & 0.146 & 0.151 & 0.135 & 0.144 & 0.151 & 0.134 & 0.106 & 0.106 & 0.123 & 0.028 & 0.001 & & \\
\hline 18 Ophiacantha richeri (NIMA95821) & 0.270 & 0.339 & 0.393 & 0.357 & 0.368 & 0.387 & 0.350 & 0.423 & 0.399 & 0.300 & 0.434 & 0.366 & 0.349 & 0.373 & 0.369 & 0.350 & 0.353 & \\
\hline 19 Ophiacantha brachygnatha (MV F146257) & 0.278 & 0.286 & 0.346 & 0.311 & 0.316 & 0.316 & 0.304 & 0.335 & 0.312 & 0.280 & 0.339 & 0.307 & 0.309 & 0.309 & 0.324 & 0.303 & 0.308 & 0.202 \\
\hline
\end{tabular}

